\title{
Media-Induced Sexual Harassment: The Routes from Sexually Objectifying Media to Sexual Harassment
}

\author{
Silvia Galdi ${ }^{1}$ - Francesca Guizzo ${ }^{2}$
}

Accepted: 28 September 2020 / Published online: 9 October 2020

(C) The Author(s) 2020

\begin{abstract}
Media that sexually objectify women by portraying them in ways that emphasize physical beauty and sexual readiness as well as reduce them to decorative and sexual objects have been traditionally identified by scholars as a powerful cultural risk factor encouraging sexual harassment and sexual violence. In the present article we review the existing empirical evidence linking sexually objectifying media and sexual harassment of women to the overarching and integrative Media-Induced Sexual Harassment framework. This framework offers a coherent scheme for explaining the effects of sexually objectifying media on three target groups directly involved in sexual harassment - perpetrators, victims, and bystanders - and it postulates three cognitive and emotional mechanisms through which sexually objectifying media lead to sexual harassment: dehumanization, disruption of emphatic resonance, and a shift in gender norms. The evidence reviewed on the basis of the Media-Induced Sexual Harassment framework shows that sexually objectifying media converge in normalizing harassing behaviors and can be a causal risk factor for increasing engagement in sexual harassment, heightening victims' acceptance of sexual harassment and discouraging bystander intervention. We discuss implications of these arguments for effectively preventing negative effects of exposure to sexually objectifying media and for education programs aimed at critical media-consumption.
\end{abstract}

Keywords Objectification $\cdot$ Mass media $\cdot$ Sexual harassment $\cdot$ Dehumanization $\cdot$ Empathy $\cdot$ Gender-role attitudes

Since October 2017 when The New York Times (Kantor and Twohey 2017) published an explosive report detailing decades of sexual harassment allegations against the film producer Harvey Weinstein, many Western countries have been taken by storm. Thousands of women have courageously broken their silence and shined a light on how pervasive sexual harassment is in the workplace as well as in public spaces (Stop Street Harassment 2018). Sexual harassment is one of the most debated topics now, and a worldwide discussion has begun about what types of behaviors qualify as harassment, what are the causes, and how to prevent and tackle the phenomenon.

The widespread prevalence of sexual harassment is problematic not only for the consequences arising for the victim

Silvia Galdi

silvia.galdi@unicampania.it

1 Department of Psychology, University of Campania Luigi Vanvitelli, Viale Ellittico 31, 81100 Caserta, Italy

2 Department of Developmental and Socialization Psychology, University of Padova, Padua, Italy and for the institution in which the harassment occurs, but also because sexual harassment is typically a precursor of severe forms of sexual violence, such as sexual assault and criminal sexual contact (Capaldi et al. 2001; Pryor 1987). Some scholars have argued that sexual harassment is especially harmful because it is rarely regarded as what it actually is, that is, a form of sexual violence (Kelly 1987; Leidig 1992; Osborne 1995; Stout 1991). This understanding suggests that if we are interested in reducing gender violence, including its more severe forms, efforts should also be invested in addressing sexual harassment and in understanding why and how harassing behaviors become part of our culture.

Therefore, in order to contribute to the current broader conversation about not only causes of sexual harassment but also policy aimed at preventing harassment incidents, in the present work, we propose the Media-Induced Sexual Harassment framework, which addresses the link between media contents that sexually objectify women (sexually objectifying media) and sexual harassment of women. To present the MediaInduced Sexual Harassment framework, we will first outline the relevant literature on sexually objectifying media, showing that they implicitly set two cultural standards: (a) how women 
ought to be (look and behave) and (b) how women ought to be treated by others (Galdi et al. 2014, 2017; Gervais and Eagan 2017). Then, we will review the existing evidence from correlational, longitudinal, and experimental studies revealing the impact of exposure to sexually objectifying media on different important outcomes that take into account three perspectives: the perpetrator (proclivity to sexual harassment), the victim (women's reactions), and the bystander (bystander intervention). We will proceed with our account of the routes from sexually objectifying media to sexual harassment by proposing three underlying psychological processes through which sexually objectifying media encourage sexual harassment: dehumanization, disruption of empathic resonance, and a shift in gender norms. We will conclude by pointing to some important suggestions for future research, as well as the practical implications of the Media-Induced Sexual Harassment framework, both for policy and practice aimed at reducing sexual harassment.

Sexual harassment is defined as unwelcome sexual advances, requests for sexual favors, and other verbal or physical conducts of a sexual nature that tend to create an intimidating, hostile, or offensive environment (Council of Europe 2011; U.S. Equal Employment Opportunity Commission 2012). According to most psychological research, harassing behaviors can be classified into three related categories: gender harassment, unwanted sexual attention, and sexual coercion (Fitzgerald et al. 1995a; Leskinen et al. 2011). Gender harassment includes sexist acts (e.g., sexist comments and slurs, obscene humor and jokes, or displaying sexual materials) that are insulting, hostile, and degrading. Unwanted sexual attention refers to unwelcome and unreciprocated gestures of sexual interest, such as an objectifying gaze, unwanted touching, or pressure for dates. Lastly, sexual coercion typically takes place in situations of power disparities and includes behaviors such as sexual blackmail, bribes, or threats aimed at receiving sexual cooperation.

From verbal to physical acts, sexual harassment occurs in every corner of the world targeting people of all gender identities, although women are the large majority of victims (European Union Agency for Fundamental Rights 2014; Stop Street Harassment 2018). Sexual harassment, moreover, can have the same severe physical, psychological, and even job-related consequences for the victim as other forms of sexual violence that are considered violent crimes, such as rape and sexual assault (Bell and Naugle 2008; Campbell 2002; Fitzgerald et al. 1997; see Cantisano et al. 2008; Willness et al. 2007, for meta-analyses). Victims of sexual harassment typically report physical effects such as headache, nausea, nightmares or disturbed sleep, loss of appetite, and weightloss (Magley et al. 1999; Willness et al. 2007). Psychological problems include general reduction in well-being, life satisfaction, and self-esteem, as well as a number of stress-related symptoms such as depression, anxiety, anger and irritability, uncontrolled crying, and burnout-related symptoms such as emotional exhaustion (Street et al. 2008). Victims can also manifest symptoms indicative of posttraumatic stress disorder, suggesting that at least some forms of sexual harassment should be considered serious trauma (see Avina and O'Donohue 2002, for a discussion). In addition, harassed people often show reduced work and academic performance and satisfaction, decreased motivation and productivity, job loss, and career interruption (Gruber and Fineran 2016; Schneider et al. 1997).

Research has also identified a number of demographic and psychological factors associated with sexual harassment. Studies have outlined the sociodemographic characteristics of prototypical victims (DeSouza 2010; Stockdale and Nadler 2012), as well as motivations and personality traits of perpetrators (Maass et al. 2013; Pina et al. 2009, for reviews). However, sociodemographic characteristics, individual motivations, and personality traits alone cannot explain differences in the likelihood of sexual harassment. Prevalence rates indeed vary greatly across countries and professional settings (e.g., European Commission, Directorate-General for Justice and Consumers 2016), thus showing that harassing behaviors and the tolerance of sexual harassment by victims and observers/bystanders (who see sexual harassment occurring but are not directly involved in the incident) are primarily a function of the general culture of a country and of the specific climate within an organization (Ilies et al. 2003; McMahon and Banyard 2012; Meraviglia et al. 2003).

Media that sexually objectify women by portraying them in ways that emphasize physical beauty and sexual readiness as well as reduce women to decorative and sexual objects (American Psychological Association 2007) have been traditionally identified by scholars as a powerful cultural risk factor encouraging sexual harassment and sexual violence (see Ward 2016, for a review). However, only recent years have witnessed the emergence of a line of research aimed at investigating the effects of sexually objectifying media on sexual harassment. Drawing from this empirical evidence, the Media-Induced Sexual Harassment framework postulates that sexually objectifying media converge in creating a cultural atmosphere that enables and reinforces the existence of sexual harassment by encouraging potential (or existing) perpetrators to engage in sexual harassment, increasing victims' tolerance for harassing behaviors, and discouraging bystanders from intervening.

Therefore, the Media-Induced Sexual Harassment framework addresses the effects of exposure to sexually objectifying media on three target groups directly involved in sexual harassment, which have been previously studied only in isolation: perpetrators, victims, and bystanders (see Fig. 1). The Media-Induced Sexual Harassment framework also highlights three interrelated cognitive and emotional mechanisms through which sexually objectifying media lead to sexual 
Fig. 1 Key tenets of the mediainduced sexual Harassment model

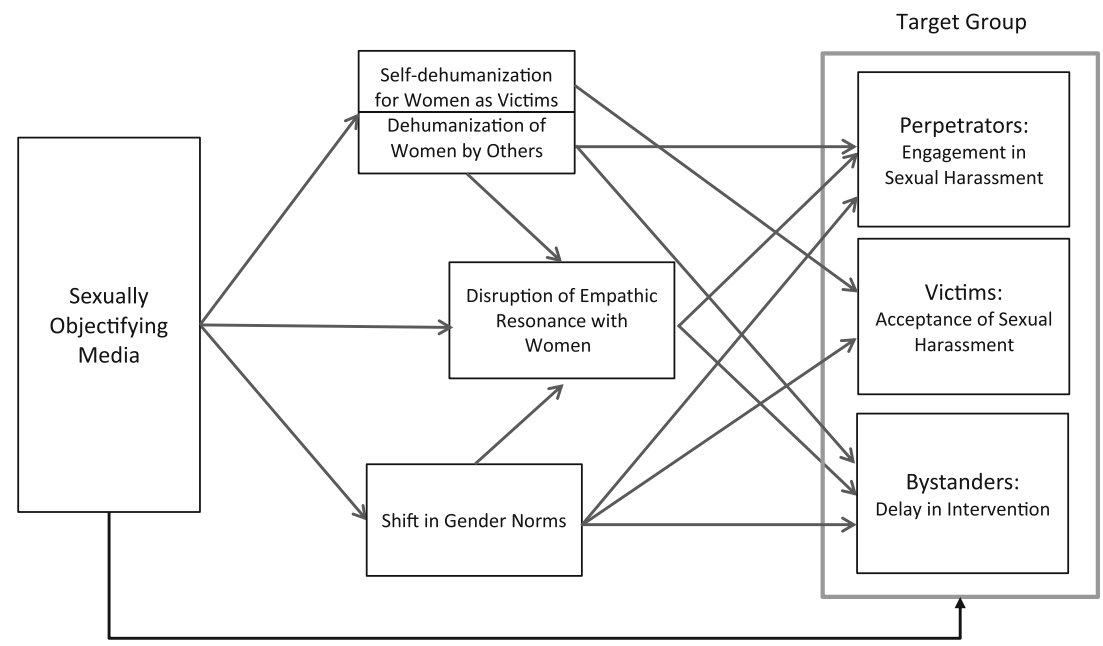

harassment: (a) changes in people's perception of women from "social category" to "object" (dehumanization), thus assimilating women to inanimate entities; (b) decreased empathy with women (disruption of emphatic resonance); and (c) shifts in people's endorsement of gender norms (shift in gender norms). As shown in Fig. 1, these three mechanisms mediate the relation between sexually objectifying media and perpetrators' engagement in harassing behaviors, as well as bystanders' intervention, whereas dehumanization (selfdehumanization, in this case) and a shift in gender norms are predicted to be responsible for victims' increased tolerance for sexual harassment. We next begin to introduce the MediaInduced Sexual Harassment framework by outlining features of sexually objectifying media.

\section{Sexual Objectification of Women in the Media}

Sexual objectification is a form of reduction to body that occurs whenever a person is fragmented into a collection of sexual body parts and functions, evaluated for her/his physical appearance, and considered as a sexual object for the use and enjoyment of someone else wherein personality, abilities, and individuality are devalued (Fredrickson and Roberts 1997; see also, Bartky 1990; Langton 2009; Nussbaum 1995). Given that we live in a male-dominated and mostly heterosexual world (Fredrickson and Roberts 1997), although men are not excluded from such treatment (Loughnan and Pacilli 2014; Martins et al. 2007), women are often the targets of sexual objectification, especially in the media.

Content analyses conducted in the United States and European countries indicate that in about one-half of commercials and advertisements women are primarily defined by their bodies, represented in piecemeal ways (i.e., showing only body parts rather than the entire figure), suggestively dressed, or posed in sexually exploitative and submissive postures, with many of these images becoming increasingly "pornified" (Conley and Ramsey 2011, in the United States; Stankiewicz and Roselli 2008, in the United States; Valtorta et al. 2016, in Italy). Along the same line, an analysis of the 100 top-fictional movies of 2018 indicates that female characters were at least three times more likely than men to be presented in sexually revealing attire (women $=29.2 \%$; men $=7.4 \%$ ) or partially or fully naked (women $=27.3 \%$; men $=8.5 \%$ ) and to be the target of comments about their appearance (women $=10.2 \%$; men $=2.7 \%$ ) (Smith et al. 2019).

The small screen does not seem to be a more progressive medium than film when it comes to portrayals of women. In contrast to their male counterparts, women in television talk less, appear less in leading (anchorwomen) or professional roles (Lauzen 2017, in the United States), and, especially in game shows, are more likely to be used as mere decorative accessories, typically dressed in no more than a bra and underwear, compared to the fully dressed male host (Glascock 2001, in the United States; Zanardo et al. 2009, in Italy). Dramatically, even children encounter on television a world in which girls and women are sexually objectified. In their analysis of American programs popular among American children, McDade-Montez et al. (2017) have recently shown that sexual objectification was present in each of the 32 episodes considered, with a total number of 770 instances, and that female characters were sexually objectified in $72 \%$ of these cases (e.g., via suggestive clothing and postures).

Furthermore, in music videos women are depicted more often than men in a sexually objectifying manner. Here, heavy emphasis is placed on women's physical appearance, body shape, and attractiveness, and portrayals frequently promote the idea that women should primarily concern themselves with attracting and sexually satisfying men (Aubrey and Frisby 2011; Vandenbosch et al. 2013; Ward et al. 2013). An analysis of 147 music videos, for example, indicates that women were often relegated to decorative roles and used (in 
the background) to elicit sexual arousal through revealing and provocative clothing, seductive dancing, or pelvic thrusting (Aubrey and Frisby 2011; see also Arnett 2002). In a similar vein, Lynch and colleagues (Lynch et al. 2016) have investigated images of women in more than 500 video games from the early 1980s through 2014 . Despite a decrease in the overall sexual objectification of female characters after 2006, results show that in some categories of video games, such as fighting games (typically targeted to a male consumer market), portrayals of women did not change over time: Female characters were frequently overtly sexually objectified - depicted with enlarged breasts or hips and narrow waists as well as shown in revealing and provocative clothing.

Although extensive data on exposure to sexually objectifying material online is lacking, sexually objectifying portrayals of women are common on the internet as well (Lambiase 2003, for a review). For example, in a recent research, web users were invited to download the first 20 pictures that appeared in Google Images when entering the words "woman" and "man" separately (Piccoli et al. 2016, in Italy). Results show that female pictures revealed more skin, were more sexualized (i.e., more sexy, attractive, and objectified), and more fragmented (i.e., only one part, compared to the full body, was presented) than male pictures.

Sexual objectification of women in the media not only is visual but also is expressed by degrading acts (often subtle and ambiguous) of men who interact with them. Women in the media are frequently the target of men's sexist jokes and statements (e.g., use of deprecating words to describe them), sexual remarks (e.g., comments about their body), and behaviors (e.g., ogling, leering, catcalling, objectifying gaze, touching). For example, entertainment TV programs in Italy often show male presenters in the presence of female assistants who serve no other purpose on the show than being targets of humiliation: They follow orders from the male host; do short, eversexier dances to please the audience and the presenter; and are often victims of the host's sexual teasing, sight gags, jokes focusing on their body parts, and physical acts of flirting, hugging, suggestive looks or touching, all of which aimed at making viewers laugh (Zanardo et al. 2009). According to one of the most used classifications of sexual harassment (see Fitzgerald et al. 1995a, 1995b; Fitzgerald and HessonMcInnis 1989), these acts are all forms of gender harassment and unwanted sexual attention. However, the humorous tone that characterizes and follows such inappropriate and unethical behaviors, as well as the absence of reactions by victims who, conversely, seem to enjoy the situation, makes them appear harmless and unproblematic.

Such treatment is not prevalent only in Italian television programs. Content analyses conducted in the United States indicate that verbal references to women as sexual objects occur 5.9 times per hour on reality dating TV shows (Ferris et al. 2007) and that harassing behaviors, such as sexist jokes, innuendo, as well as other offensive comments about female characters, constitute very common messages in situation comedies (Kim et al. 2007; see also Grauerholz and King 1997). Acts ranging from sexual innuendo and jokes to inappropriate touching and requests for sexual favors were also found on most American situation comedies analyzed by Montemurro (2003). In a similar vein, Fouts and Burggraf (2000, in Canada) showed that the way female characters were treated on situation comedies was dependent on their body size: Women who were either average or above average in weight were treated more negatively than those who were thinner than average.

To summarize, sexual objectification of women is commonplace in the media across multiple formats. Evidence also indicates that media, and television in particular, sexually objectify women via two insidious routes (Galdi et al. 2014, 2017; Gervais and Eagan 2017). The first route is via the role assigned to women, which includes a strong emphasis on their bodies, appearance, and sex appeal, along with a tendency to often use women as decorative elements to attract attention. This route communicates the notion that women are valued primarily for their bodies, beauty, and sexiness rather than for who they are or what they can do. A recent example of this media bias came when a TV sport commentator asked Canadian tennis star Eugenie Bouchard to twirl and show off her outfit. At the time of this request Bouchard had just finished dominating her opponent in the 2015 Australian Open. Unfortunately, it is not rare to run across media formats in which, when they are active and competent, women are prized not only for their achievements and performances, but also for their appearances. For instance, in the summer of 2017, there was a debate in American television about whether female Olympic athletes should wear makeup. Therefore, through the first route, media demand that women are primarily good-looking and sexually desirable and convey the idea that women are valued predominantly for their physical appearance and attractiveness.

The second route is via the verbal and behavioral reactions of those who interact with women. This route conveys the message that it is normal (and funny!) to depreciate, diminish, and harass women, thus defining how they should be treated. In support of this contention are findings from a content analysis by Kim and collaborators (2007), who investigated sexual content on American television to evaluate portrayals of heterosexuality and heterosexual romantic relationships. The authors found that the most frequent message conveyed by primetime sitcoms and dramas was about men and how men think, feel, and behave in romantic and sexual relationships. According to this message, being sexual initiators, actively exhibiting sexual prowess, and accumulating sexual experience with women are important, desirable, and even necessary components of masculinity. Results also indicate that one of the most common ways in which television programs linked sexuality to masculinity was by men sexually objectifying 
women, unabashedly ogling female characters, openly valuing and judging women by their physical appearance, and treating women as mere objects of desire. Importantly, these behaviors were often depicted as playful, light-hearted, and inconsequential. Therefore, even when media portray masculine identities, they define not only how men should be and behave, but also how they ought to treat women.

Although influences on sexual harassment include a variety of personal, interpersonal, and even social factors, scholars have established that culture plays an indisputable role (Armstrong et al. 2006; Banyard 2011; Glomb et al. 1999; Hesson-Mcinnis and Fitzgerald 1997). According to many communication theorists, media can have an influential role in shaping culture (see Bryant and Oliver 2009). Media narratives and images indeed not only reflect and maintain, but also provide symbols, myths, and resources that mold the prevalent view of the world, including norms and values (Cialdini and Trost 1998). Therefore, through the two routes we highlighted, sexually objectifying media become a pivotal factor that provides the materials that contribute to creating a culture that potentially sexually objectifies women and reduces them to sexual objects (see also Fredrickson and Roberts 1997).

In such a cultural context, sexual harassment may become normal and normative. After all, sexual harassment is a typical case in which a woman is considered and treated as a sexual object. The Media-Induced Sexual Harassment framework postulates that sexually objectifying media contribute to condoning sexual harassment, thus increasing its likelihood, because they (a) encourage perpetrators to act out harassing behaviors (perpetrator perspective), (b) induce victims to tolerate the incident of sexual harassment (victim perspective), and (c) discourage bystanders from realizing that sexual harassment is occurring and from intervening promptly in favor of the victim (bystander perspective). In the next sections, we will review existing findings supporting each of these claims. This evidence is also summarized in Table 1.

\section{The Perpetrator's Perspective}

Sexual harassers permeate all social strata, occupational levels, and age categories (see Pina et al. 2009, for a review). Although it is difficult to define sociodemographic characteristics of the typical perpetrator, it is relatively easy to identify individuals with a high harassment proclivity. Men's proclivity to harass is generally assessed through the Likelihood of Sexual Harassment Scale (LSH, Pryor 1987), which predicts engagement in harassing behaviors (Dall'Ara and Maass 2000) and correlates with a number of critical individual difference variables, such as stronger endorsement of traditional gender roles, hostile sexism, masculine ideology, authoritarianism, social dominance orientation, and rape myth acceptance, as well as lower levels of agreeableness and empathy (see O'LearyKelly et al. 2009, for a review).

Research has also identified three basic motivations underlying engagement in sexual harassment: (a) desire for sexual favors, (b) needs for power and dominance, and (c) gender identity enhancement/protection (Maass et al. 2013). Whereas the desire for sex and need for power and dominance typically drive behaviors of unwanted sexual attention and sexual coercion (Bargh et al. 1995; Pryor et al. 1993), gender identity enhancement/protection has been found to be the driving force behind gender harassment. Based on social identity theory (Tajfel and Turner 1986), gender harassing behaviors, which are primarily aimed at offending and demeaning women, may constitute a means of outgroup discrimination that derives from the desire to enhance one's gender identity as male or to defend it when that identity is threatened (Dall'Ara and Maass 2000; Maass et al. 2003).

Sexual harassment also may depend on exposure to sexually objectifying media that operate by affecting men's personal beliefs, predispositions, and motivations. For example, after exposure to movies, magazines, music videos, or TV clips showing sexually objectified women, men tended to manifest greater tolerance for behaviors of unwanted sexual attention, sexual coercion, and sexual harassment than participants without this exposure (Aubrey et al. 2011, in the United States; Bernard et al. 2018, in Belgium; Kistler and Lee 2009, in the United States; see also Hust et al. 2019, for correlational evidence in the United States). Similar results have been obtained among video game players. Compared to playing neutral video games, playing video games that include sexually objectifying female characters increased boys' (ranging from 12 and 15 years of age) rape myth acceptance (Driesmans et al. 2015, in Belgium) as well as male adults' and adolescents' tolerance for sexual harassment (Dill et al. 2008, in the United States; Driesmans et al. 2015; but see Vance et al. 2015, in the United States).

Furthermore, sexually objectifying media may have immediate effects on how men behave toward women. Playing with sexually objectifying (vs. non-sexually objectifying) video games increased men's self-reported tendency to sexually harass (Yao et al. 2010, in the United States). Men exposed to sexually objectifying TV commercials were more likely to exhibit gender harassing behaviors, such as sitting closer and asking a female confederate sexist and inappropriate questions during a subsequent alleged job-interview, than participants in a control condition (Rudman and Borgida 1995, in the United States). In a similar vein, after exposure to sexually objectifying movie clips, male participants asked more sexist questions during a mock job interview than those who were not exposed to such content (Hitlan et al. 2009, in the United States). Moreover, after watching a sexually objectifying TV clip men manifested higher intention to engage in sexual coercion (assessed via the LSH; Pryor 1987), and were more prone to 
Table 1 Studies supporting the direct path from sexually objectifying media to sexual harassment as a function of target group involved in the incident

\begin{tabular}{|c|c|c|c|c|}
\hline Study & Sample & Method & Media type & Outcome \\
\hline \multicolumn{5}{|l|}{ (a) Target Group: Perpetrators } \\
\hline Aubrey et al. 2011 & Men & Experimental & Music videos & Tolerance for sexual harassment \\
\hline Bernard et al. 2018 & Men and women & Experimental & Television & Tolerance for sexual harassment \\
\hline Dill et al. 2008 & Male adolescents & Experimental & Video games & Tolerance for sexual harassment \\
\hline Driesmans et al. 2015 & Male and female adolescents & Experimental & Video games & $\begin{array}{l}\text { Tolerance for sexual harassment, } \\
\text { rape myth acceptance }\end{array}$ \\
\hline Galdi et al. 2014 & Men & Experimental & Television & Gender harassing behaviors \\
\hline Hitlan et al. 2009 & Men & Experimental & Movies & Gender harassing behaviors \\
\hline Hust et al. 2019 & Men and women & Correlational & Magazines & Intention of sexually coercing \\
\hline Kistler and Lee 2009 & Men and women & Experimental & Music videos & Tolerance for unwanted sexual attention \\
\hline Rudman and Borgida 1995 & Men & Experimental & Advertisement & Gender harassing behaviors \\
\hline Yao et al. 2010 & Men & Experimental & Video games & Willingness to sexually harass \\
\hline \multicolumn{5}{|l|}{ (b) Target Group: Victims } \\
\hline Driesmans et al. 2015 & Male and female adolescents & Experimental & Video games & $\begin{array}{l}\text { Tolerance for sexual harassment, } \\
\text { rape myth acceptance }\end{array}$ \\
\hline Fox et al. 2015 & Women & Experimental & Video games & Rape myth acceptance \\
\hline Haferkamp 1999 & Men and women & Correlational & Television & Dysfunctional relationship beliefs \\
\hline Johnson et al. 1995 & Male and female adolescents & Experimental & Music videos & Tolerance for dating violence \\
\hline Reichl et al. 2018 & Men and women & Experimental & Advertisement & Tolerance for sexual coercion \\
\hline Strouse et al. 1994 & Male and female adolescents & Correlational & Music videos & Tolerance for sexual harassment \\
\hline \multicolumn{5}{|l|}{ (c) Target Group: Bystanders } \\
\hline Foubert et al. 2011 & Men & Correlational & $\begin{array}{l}\text { Movies, magazines, } \\
\text { internet }\end{array}$ & $\begin{array}{l}\text { Willingness to intervene in sexual } \\
\text { assault incidents }\end{array}$ \\
\hline Galdi et al. 2017 & Men & Experimental & Television & Intervention in a sexual harassment incident \\
\hline Hansen and Hansen 1988 & Men and Women & Experimental & Music videos & Appropriateness of harassing behaviors \\
\hline Holland and Haslam 2016 & Men and Women & Experimental & Advertisement & Willingness to help \\
\hline Hust et al. 2013 & Men and Women & Correlational & Sport programming & $\begin{array}{l}\text { Willingness to intervene in sexual } \\
\text { assault incidents }\end{array}$ \\
\hline
\end{tabular}

engage in actual gender harassing behaviors, namely to send sexist and offensive jokes to an unknown (alleged) female chatline partner, as compared to a control video and to TV content that featured professional women (Galdi et al. 2014, in Italy).

Therefore, men exposed to sexually objectifying media may be more likely to show a stronger post-exposure endorsement of attitudes supportive of sexual harassment, as well as to engage in actual harassing behaviors in everyday encounters both in job-related and general social contexts, as compared to those exposed to no content or neutral material. Evidence also shows that such effects increase specifically in reaction to mere exposure to sexually objectifying contents, but not to other portrayals of women in the media.

\section{The Victim's Perspective}

We now move to outline some important effects of exposure to sexually objectifying media on women as potential victims of sexual harassment. As we noted previously, sexual harassment can have severe consequences for the victim's health and psychological well-being, as well as severe effects related to work and school, thus ultimately impacting communities and society (see Cantisano et al. 2008; Willness et al. 2007). Exacerbating these consequences, most victims are subjected to repeated experiences of sexual harassment rather than isolated incidents (Stop Street Harassment 2018). The \#MeToo movement, which began in the United States in 2017, seems to have created a change, leading women from all over the world to expose their experiences of sexual harassment and perpetrators to face the aftermath of their actions. Nonetheless, even nowadays only 1 in 10 women files an official complaint or reports a harassment incident to an authority figure, including filing a police report (Stop Street Harassment 2018).

Why do victims often react passively (e.g., avoiding the harasser or denying the experience; European Union Agency for Fundamental Rights 2014), do not claim their rights, or simply ignore the harassment rather than reporting the incident to authorities or to supervisors? Such reactions may have different explanations, including fear of retaliation and of lack 
of support (Fitzgerald et al. 1995b); fear of being blamed for the incident or of not being believed; fear that the occurrence was not harmful enough; and/or shame, embarrassment, or uncertainty that sexual harassment was committed (European Union Agency for Fundamental Rights 2014; LeMaire et al. 2016). The Media-Induced Sexual Harassment framework postulates an additional reason: exposure to sexually objectifying media that may lead women to be more tolerant toward sexual harassment.

Sexually objectifying media indeed rely on two primary channels, namely the demeaning role assigned to woman and acts of actual gender harassment and unwanted sexual attention of others (by men, in particular) who interact with her. Through the latter channel, media normalize sexual harassment and convey the harmful message to women that they can be openly harassed, in that sexual harassment is a joke and/or an innocuous male behavior of (sexual) interest.

Consistently, regular exposure to TV genres such as soap operas has been found to be related to greater acceptance of dysfunctional relationship beliefs among women (Haferkamp 1999, in the United States). In a similar vein, female adolescents' greater exposure and involvement with music videos correlated with acceptance of unwanted sexual advances and sexual comments (Strouse et al. 1994, in the United States). These correlational findings have been corroborated by experimental research. After exposure to sexually objectifying ads, women showed greater minimization of instances of sexual coercion compared to participants exposed to ads including active and competent women or ads with latent themes of abuse and victimization of women (e.g., women in potentially dangerous locations, women held by men in vulnerable positions; Reichl et al. 2018, in Canada). In a similar vein, playing with a sexually objectifying video game led to greater tolerance of sexual harassment among female adolescents compared to neutral video games (Driesmans et al. 2015, in Belgium). Further, young women exposed to sexually objectifying music videos were more accepting of dating violence than were female adolescents without such exposure, whereas male adolescents' attitudes did not differ between conditions (Johnson et al. 1995, in the United States). In addition, higher levels of rape myth acceptance have been found among women who were placed in sexually objectified compared to nonsexually objectified virtual bodies in an online video game (Fox et al. 2015, in the United States; see also Driesmans et al. 2015).

Therefore, some experimental studies show that a path from sexually objectifying media to women's tolerance of sexual harassment may exist. Given this evidence, one could argue that if women are more willing to accept sexual harassment, then they will also be less likely to react or to report the harassment incident to authorities or to supervisors. Thus, it becomes critical to explore other control mechanisms, such as bystander intervention.

\section{The Bystander's Perspective}

To date, the main theoretical framework of reference for many studies and models on bystander intervention in situations of sexual harassment and sexual violence (Bowes-Sperry and O'Leary-Kelly 2005; Burn 2009; Foubert et al. 2011; Hust et al. 2013; Nickerson et al. 2014) is the classic work conducted by Latané and Darley (1970). According to Latané and Darley, bystander intervention is the product of a five-step decision-making process, where the first two critical steps require the observer to notice the event and recognize it as problematic and harassing for the victim. Helping responses are indeed more likely when the situation is interpreted as a clear-cut emergency or ethical problem (O'Leary-Kelly and Bowes-Sperry 2001; see Fischer et al. 2011, for a meta-analytic review). However, the harassing incidents that are more likely to be witnessed are acts of gender harassment and unwanted sexual attention (Fitzgerald et al. 1995a, 1995b), which include the most ambiguous harassing behaviors. These acts, indeed, are often covert, subtle, and related to "everyday behaviors" (e.g., sexist jokes, degrading language, displaying sexual material, ogling; McMahon and Banyard 2012; McMahon et al. 2011) and, importantly, they do not pose a clear immediate or high risk of harm to victims (Banyard 2011; Stout 1991). Compared to sexual coercion and sexual violence, the covert and ambiguous nature of gender harassment and unwanted sexual attention may therefore challenge the bystander's sense making of the incident (Bowes-Sperry and O'Leary-Kelly 2005; McMahon and Banyard 2012), thus representing an interfering factor in actual intervention.

The Media-Induced Sexual Harassment framework postulates that sexually objectifying media may further complicate the bystander's task. Indeed, sexual objectification of women in the media is often expressed through behaviors of gender harassment and unwanted sexual attention (e.g., sexist remarks, leering, objectifying gaze, touching) in which victims give the impression that they enjoy such treatment. In this way, sexually objectifying media not only contribute to the belief that sexual harassment is innocuous and normal but also may lead individuals to fail to recognize harassment incidents as such when encountering them in the real world, thus influencing helping responses. Evidence consistent with our reasoning comes from a study by Hansen and Hansen (1988, in the United States), who demonstrated that the media contents just watched may affect viewers' interpretation of an actual incident of sexual harassment. After exposure to sexually objectifying music videos, participants appraised an interaction between a male and a female job applicant. Participants who watched the music videos prior to viewing the interaction were more likely to evaluate the man's harassing behaviors of unwanted sexual attention as appropriate and judged the male as more skilled when he derogated the woman for not reciprocating. Conversely, participants who watched neutral videos recognized the man's behaviors as harassing and judged the 
woman more favorably when she did not reciprocate his advances.

Other research has shown that sexually objectifying media may decrease viewers' willingness to provide help. For example, exposure to sports programs showing sexually objectified female athletes was found to be negatively associated with both male and female participants' intentions to provide help in sexual assault incidents (Hust et al. 2013, in the United States; see also Foubert et al. 2011, in the United States). As a direct application of the Media-Induced Sexual Harassment framework, Galdi et al. (2017, in Italy) first exposed participants to a sexually objectifying or to a control TV clip. As observers, participants then assisted at an alleged job interview between a male interviewer and a female job applicant via computer-chat. The chat interview was constructed so as to become increasingly harassing as time passed: It started with general neutral questions and progressed with sexist and gender-harassing statements (e.g., "Given that I rather like you, I'll tell you a joke... Why are women claimed to have supernatural powers? Because they are able to lift something without touching it!'), ending with overt and offensive sexual interests (e.g., "When you are in bed, are you as good as you are now in your verbal abilities?") and pressure for dates. Participants had the opportunity to intervene interactively in the chat at any time and whenever they felt it appropriate, either in favor of the interviewer or the job applicant. Results showed that, compared to those who had viewed the control clip, participants (both men and women) exposed to the sexually objectifying TV clip took more time before realizing that the interviewer's questions were harassing, and, importantly, they also intervened in favor of the victim later.

To summarize, according to the dominant trend in communication research, both women and men can be affected by media exposure (Ward 2016; see also Wright et al. 2016, for a meta-analytic review). The findings we briefly reviewed here support this evidence and show that sexually objectifying media may have at least short-term effects on likelihood of sexual harassment by (a) encouraging harassing behaviors, (b) influencing women's tolerance for sexual harassment, and (c) discouraging bystanders from intervening promptly in favor of the victim (see Table 1 for a summary). This evidence, however, does not speak about how sexually objectifying media increase sexual harassment. In the next section we will first outline the theoretical perspective underlying the MediaInduced Sexual Harassment framework and then we will address the issue of mechanisms.

\section{The Theoretical Perspective and Underlying Mechanisms}

The Media-Induced Sexual Harassment framework draws from cognitive theories focusing on schema or script activation and accessibility (e.g., Huesmann 1986; Wright 2011; see Fiske and Taylor 1991; Srull and Wyer 1989, for reviews), which, we believe, provide a straightforward rationale for how media shape consumers' attitudes, beliefs, and behaviors. According to this perspective, schemas or constructs are abstract knowledge structures, stored in long-term memory, that specify the defining features and attributes of a given concept, object, or target (Macrae et al. 1996) as well as its relation to other concepts (Huesmann 1998). Schemas or constructs may also contain behavioral scripts (Fiske and Linville 1980), namely socially constructed guidelines that signal to individuals what behaviors are expected in a specific setting or in response to a specific concept, object, or target (Schank and Abelson 1977). Moreover, schemas or constructs can be acquired and can evolve or be adjusted through direct experience or secondhand sources, such as the media (Crocker et al. 1984). The Media-Induced Sexual Harassment framework postulates that by depicting how women should look and behave and how women can be treated by others as suitable and typical, sexually objectifying media set two cultural standards that contribute to shaping (or even creating; Bandura 2001; Wright 2011) a specific construct, such as the construct of women as sexual objects.

Schemas or constructs that come to mind, thus becoming more likely to be applied, can be affected by accessibility, that is, the extent to which they are at the forefront of the mind (Higgins 1996; Sanna and Schwarz 2004). Accessibility, in turn, is a function of the recency and frequency with which a specific schema or construct has been used. The expansive literature on priming effects (Berkowitz and Rogers 1986) has established that schemas or constructs that have been activated in unrelated contexts may continue to automatically (without intention or awareness) exert an influence on judgments and behavior because their previous use has rendered them temporarily highly accessible (Bargh 1996; Bargh et al. 1996; Higgins and Bargh 1987). For example, after exposure to words related to kindness or hostility, participants judged an ambiguous, hypothetical situation according to the construct with which they had been initially presented (Srull and Wyer 1979). In a similar vein, participants were more likely to exhibit violent behaviors in unrelated situations after being exposed to violent media images (Bushman 1995; Josephson 1987).

This existing evidence shows well that situational factors or the presentation and processing of a stimulus with a particular meaning may make the related schemas or constructs temporarily highly accessible, thus increasing significantly the likelihood that subsequently encountered stimuli or events will be appraised in the context of such structures. However, frequent and consistent experience with specific concepts, objects, or targets may render relevant schemas or constructs chronically accessible, that is more likely than others to be used across time and situations (Chen and Andersen 1999; 
Dijksterhuis and van Knippenberg 1996; Higgins and Brendl 1995; Rudman and Borgida 1995). Importantly, whereas the temporary accessibility of a schema increases the probability of short-term effects (see Bodenhausen and Macrae 1998, for a review), chronic accessibility leads to long-term effects on judgments and behaviors (Chen and Andersen 1999; Dijksterhuis and van Knippenberg 1996; Higgins and Brendl 1995; Rudman and Borgida 1995).

An important implication of schema or construct accessibility is its utility in relation to impression formation. Research has established that categorization is the means by which a schema or construct is accessed, used to draw inferences, and form an impression about a target person (Zarate and Smith 1990). Therefore, different defining characteristics, attributes, and behaviors will be enhanced and hence ascribed to a person, depending on how they are classified (e.g., based on gender or their work, social role). Applying this theorizing and evidence to the present issue, the Media-Induced Sexual Harassment framework postulates that exposure to sexually objectifying media represents a situational factor that leads consumers to categorize women as sexual objects, thus boosting the temporary accessibility of the corresponding harmful construct. In this way, the likelihood that information included in this structure will be used to appraise, form an impression about, or behave toward women subsequently encountered in the real-world increases significantly.

Evidence that sexually objectifying media enhance the temporarily high accessibility of the construct of women as sexual objects and hence its applicability even to nonobjectified women and in inappropriate contexts has been well provided by Rudman and Borgida (1995). The authors demonstrated that after exposure to sexually objectifying television commercials, male participants interpreted the ambiguous stimuli included in a lexical decision task (i.e., doubleentendres such as cherry, easy, strip) consistently with the construct made accessible by the commercials (i.e., women as sexual objects), whereas men in the control condition interpreted the same words as neutral stimuli. Participants exposed to sexually objectifying commercials were also more likely to indulge in gender-harassing behaviors during a subsequent interview with an unknown female job applicant (see also Yao et al. 2010, for similar results). Moreover, after the interview, these same participants recalled more of the physical attributes of the female job applicant and less of the substantive information compared to those exposed to neutral content.

However, if we are frequently exposed to sexually objectifying media, the construct of women as sexual objects is frequently activated; frequent activation, in turn, can gradually increase the likelihood that this particular way of viewing women will become more generally and easily available to be used. Given that sexual objectification is commonplace in the media across multiple formats, sexually objectifying media may therefore become a crucial factor that contributes to making the construct of women as sexual objects chronic, thus contributing to a cultural context that potentially legitimates a degrading model of women and the existence of sexual harassment.

The Media-Induced Sexual Harassment framework is very close to the acquisition, activation, application model (3 AM; Wright 2011), an excellent recent multi-component perspective on how media contents contribute to increase violence against women. The 3 AM model posits that sexual media contents provide consumers with (or prime previously acquired) sexual scripts that define specific sexual behaviors and roles, the principles of which may be abstracted and applied to behaviors and roles that were not depicted (Wright 2011; Wright and Funk 2014; Wright et al. 2012). According to the $3 \mathrm{AM}$, the specific script that sexually objectifying media provide people is the notion that women are objects that exist for men's sexual gratification. This perspective on women, in turn, may be used to inform attitudes toward and violence against women (Wright and Tokunaga 2016).

Importantly, according to this model the mechanism through which media exert their influence on consumers' behavior is (abstract) scripting. Unlike the 3 AM model, the Media-Induced Sexual Harassment framework postulates that the accessibility of the construct of women as sexual objects boosted by exposure to sexually objectifying media may affect potential perpetrators', victims', and bystanders' behaviors through three mechanisms of cognitive, emotional, and normative nature: (a) dehumanization, (b) disruption of emphatic resonance, and (c) shift in gender norms, respectively. We will therefore discuss each of these mechanisms in the next sections, also incorporating whenever possible findings that corroborate the statements of the Media-Induced Sexual Harassment framework. The evidence supporting the relation between sexually objectifying media and each mechanism is also summarized in Table 2.

\section{Sexually Objectifying Media $\rightarrow$ Dehumanization}

Dehumanization can be a worrying and degrading consequence of sexual objectification of women (Loughnan and Pacilli 2014; Vaes et al. 2014; Vaes et al. 2011). Research has established that sexually objectified women, but not men, not only are visually processed in a piecemeal fashion, similar to the processing style involved in the recognition of objects (Bernard et al. 2012; Cogoni et al. 2018a; Gervais et al. 2012; see also Bernard et al. 2013; Civile and Obhi 2016; Schmidt and Kistemaker 2015; Tarr 2013, for a debate), but also are perceived as more similar to real objects (Vaes et al. 2019).

These effects of sexual objectification can also extend beyond how a woman is cognitively processed and perceived. Sexually objectified women are appraised as less than humans 


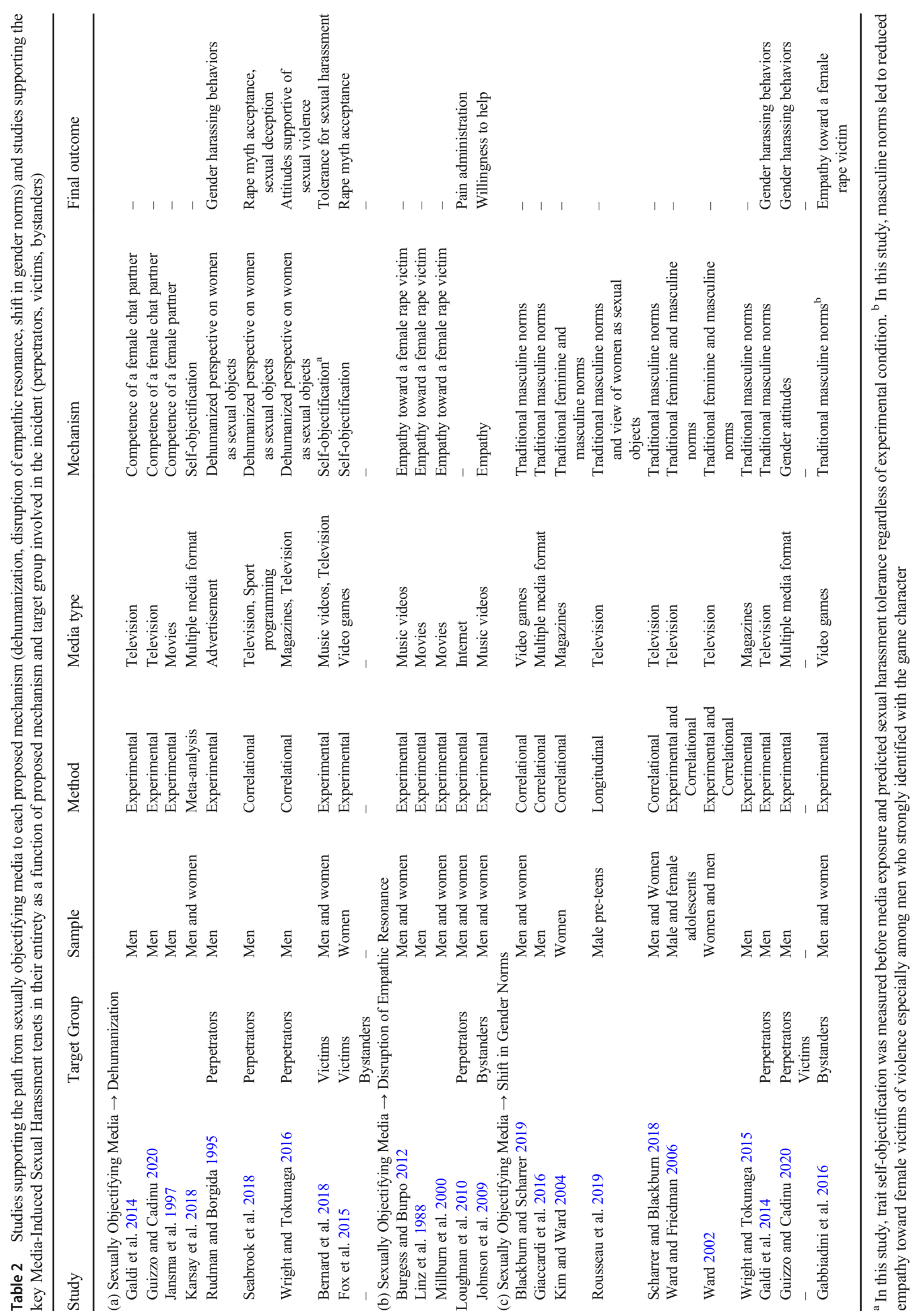


(Morris et al. 2018; Vaes et al. 2011; see also Pacilli et al. 2019 , for similar results among children) and as deprived of their mind and agency (Cikara et al. 2011; Gray et al. 2011), all of which are core characteristics that distinguish human beings from animals and objects (see Heflick and Goldenberg 2014, for a review). Also, people tend to attribute to sexually objectified women less competence and intelligence (Fasoli et al. 2018; Glick et al. 2005), and less warmth and morality (Heflick and Goldenberg 2009; Heflick et al. 2011; Loughnan et al. 2010; Pacilli et al. 2017). Therefore, this literature indicates that sexually objectified women tend to be seen as lacking some of the most basic aspects of personhood.

Applying this evidence to the present issue, the MediaInduced Sexual Harassment framework postulates that the model of women activated by exposure to sexually objectifying media (i.e., the concept of women as sexual objects) may trigger a cognitive shift in people's perception of women as a whole from "social category" to "object" (i.e., dehumanization). This cognitive shift, in turn, may affect the way in which women in real life are perceived and treated. Consistently, men (especially those with stronger endorsement of masculine norms) who viewed sexually objectifying movies subsequently rated their female partner's intellectual competence lower than did participants who were not exposed to such contents (Jansma et al. 1997, in the United States). In a similar vein, exposure to television depictions of sexually objectified women affected male participants' impression of a fictitious female partner encountered during a subsequent chat interaction (Galdi et al. 2014, Study 1, in Italy; see also Guizzo and Cadinu 2020, Study 1, in Italy). Although there was no logical connection between the women portrayed in the objectifying TV clip and the unknown female chat partner, participants judged the interaction partner as less competent after watching the sexually objectifying TV clip as compared to nature images or non-objectified professional women.

Studies on everyday media use have also led to the recognition of a relation between exposure to sexually objectifying media, dehumanization of women, and sexual harassment. For example, the more men regularly consume sexually objectifying media, such as magazines, reality TV programs, sitcoms, and drama programs, the more likely they are to think of women as mere objects that exist for men's sexual pleasure (Seabrook et al. 2018, in the United States; Wright and Tokunaga 2016, in the United States). This dehumanized perspective on women, in turn, has been found to predict rape myth acceptance (Seabrook et al. 2018), attitudes supportive of sexual violence (Wright and Tokunaga 2016), and engagement in behaviors of sexual deception (e.g., lying about one's identity or feelings to gain sexual favors or inducing potential partners to get drunk or stoned in order to have sex with them; Seabrook et al. 2018). Corroborating this correlational evidence, Rudman and Borgida (1995, in the United States) showed that after exposure to sexually objectifying commercials, men were more likely not only to think of women as sexual objects, but also to exhibit inappropriate genderharassing behaviors in a subsequent interaction with a nonobjectified female confederate than participants in a control condition.

As postulated by the Media-Induced Sexual Harassment framework, dehumanization of women is also responsible for reduced bystander intervention. No known research to date has directly investigated the relation among sexually objectifying media, dehumanization of women as a whole, and bystanders' behavior. Nonetheless, preliminary support to this prediction shows that both men and women were less willing to help when the victim of an incident of sexual harassment, portrayed in a fictitious online newspaper article, was sexually objectified versus non-sexually objectified (Gramazio et al. 2019, in Italy). In their study, reduced willingness to help was driven by increased victim-blame and decreased attribution of morality, a fundamental dimension related to human beings (see also Holland and Haslam 2016, for similar results, in Australia). Similar evidence was reported by Pacilli et al. (2017, in Italy) who demonstrated that sexually objectified victims are seen as less capable of suffering and as lacking moral standing. The authors also found that when the victim of intimate partner violence is portrayed in sexually objectifying (vs. non-objectifying) manner by social media, people report less willingness to intervene on her behalf. Importantly, the data showed that decreased attribution of moral patiency (i.e., the capability of experiencing pain) mediated the link between sexual objectification of the victim and reduced bystander intervention.

Therefore, when victims of gender violence are sexually objectified in the media, viewers may dehumanize them and manifest reduced willingness to provide them with help. This evidence suggests that dehumanization triggered by the concept of women as sexual objects might also contribute toward explaining the relation between exposure to sexually objectifying media and reduced bystander intervention in cases of sexual harassment (Galdi et al. 2017).

Turning specifically to women as potential victims of sexual harassment, according to objectification theory (Fredrickson and Roberts 1997), the way women and their bodies are represented in the media contributes to the creation of a cultural context that potentially sexually objectifies women and establishes how they should be or appear. This cultural context can coax women and girls to self-objectify, that is, to focus on their appearance attributes and to adopt an observer's perspective on their physical selves. This focus on the body and physical appearance may ultimately lead women to treating and experiencing themselves as objects to be looked at and evaluated as well as instruments to satisfy the needs and desires of others. Since the introduction of objectification theory, an abundance of research has accumulated demonstrating 
a link among exposure to sexually objectifying media, selfobjectification, and a variety of harmful psychological and health consequences among girls and women, such as appearance anxiety, body shame, self-surveillance, body dissatisfaction, self-disgust, eating disorders, and depression (see Grabe et al. 2008; Karsay et al. 2018, for meta-analyses).

Self-objectification, however, can also imply self-dehumanization. Some studies have indeed shown that self-objectified women perceive themselves as powerless and as lacking the means to make autonomous decisions (Yang et al. 2015), that is, they perceive themselves as less than human. In a similar vein, Baldissarri et al. (2019) have recently found that compared to participants in non-objectifying and control conditions, after receiving comments focusing on their physical appearance women self-attributed fewer human mental states and lower free will as well as perceived themselves more as being an instrument rather than as a human being. Furthermore, after recollecting instances of sexual objectification, female participants rated themselves as less warm, competent, and moral as well as lacking in human nature and human uniqueness (Loughnan et al. 2017; see also Chen et al. 2013). It is worth noting that women who self-objectify also tend to dehumanize other women (Puvia and Vaes 2013).

Is it possible that self-dehumanization increases women's tolerance for harassment? Bernard and collaborators (2018, in Belgium) have found that tolerance for sexual harassment increased among undergraduate students the more they selfobjectified. A similar pattern emerges for sexually objectifying media. For example, after playing in a virtual environment with a sexually objectified (vs. non-sexually objectified) avatar, women were more likely to self-objectify and to endorse rape myth acceptance (Fox et al. 2015, in the United States). Importantly, self-objectification mediated the relation between experimental condition (playing with a sexually objectified vs. a non-sexually objectified avatar) and subsequent greater rape myth acceptance. Therefore, evidence supports the link between exposure to sexually objectifying media and self-objectification - a state that may also imply a specific cognitive shift in women's self-construal from human being to less than human (self-dehumanization). Self-objectification, moreover, not only may affect women's views of themselves, but also may induce them to dehumanize other women, endorse attitudes that condone sexual violence, and manifest greater tolerance for sexual harassment.

\section{Sexually Objectifying Media $\rightarrow$ Disruption of Emphatic Resonance}

Research has established that lack of empathy, an emotional mechanism of moral disengagement (Bandura 1999), is one of the most defining personality traits of sexual assailant and sexual harasser profiles (see Awasthi 2017; Pina et al. 2009, for reviews). Moreover, lack of empathic resonance is associated with sexual offense and sexual harassment proclivity (Bartling and Eisenman 1993; Geer et al. 2000; Pryor 1987). Empathy has also been linked with helping behaviors (Eisenberg and Fabes 1990) and defending victims of bullying and sexual violence (Banyard 2011; Caravita et al. 2009).

As postulated by the Media-Induced Sexual Harassment framework, the accessibility of the construct of women as sexual objects boosted by sexually objectifying media disrupts empathic resonance with women, thus encouraging harassing behaviors and discouraging bystander intervention. Preliminary support to this claim comes from a recent line of research on empathy with sexually objectified women. For example, Cogoni, Carnaghi, and Silani (2015, in Italy) have adopted the Empathy for Affective Touch paradigm, a task based on a visuo-tactile stimulation of the participant and of a confederate acting as a second participant. Depending on the experimental condition, the confederate was a mannequin (i.e., a human-like object), a sexually objectified woman (i.e., a woman dressed in a sexually objectifying manner), or a non-sexually objectified woman. Tactile stimulation consisted of touching the participant's or the confederate's palm with materials that, when combined with matching pictures, may solicit either a pleasant, an unpleasant, or a neutral feel. Participants' task was to evaluate their personal emotional experience as well as rate how the confederate was feeling during the stimulation. Participants reported more empathy when interacting with non-sexually objectified women than when interacting either with sexually objectified women or with mannequins.

Other evidence indicates that, at the brain level, empathy for victims of social exclusion recruits areas coding the affective and the somatosensory components of pain. However, this happens to a greater extent when the social exclusion is experienced by non-sexually objectified rather than by sexually objectified women (Cogoni et al. 2018b, in Italy). These effects have been extended to sexually objectifying media images. For example, Loughnan et al. (2010, country not specified) have investigated empathy with targets depicted in a sexually objectifying manner by media (i.e., pictures of women in bikinis and shirtless men taken from the internet). As in many studies on empathy, the authors operationalized empathy by measuring participants' tendency to administer pain to the sexually objectified targets (Decety and Jackson 2004; Jackson et al. 2005; Singer et al. 2004). Results showed that both male and female participants manifested more willingness to administer pain to the sexually objectified than nonsexually objectified targets. Therefore, empathy can be disrupted and the tendency to harm can increase if the target is sexually objectified both within and outside the media. This evidence suggests that the concept of women as sexual objects activated by sexually objectifying media may reduce empathy with women, thus increasing the likelihood of harmful behaviors including sexual harassment. 
Turning to bystanders, research has shown that exposure to sexually objectifying clips or movies decreases empathy toward the female victim of a rape incident as well as toward rape victims in general (Burgess and Burpo 2012, country not specified; Linz et al. 1988, in the United States; Millburn et al. 2000 , in the United States). To our knowledge, only one study to date has explored the relation among sexually objectifying media, empathy, and bystander intervention. After exposure to music videos depicting sexually objectified Black women in provocative poses and movements, participants manifested reduced willingness to provide help to a Black woman in need (Johnson et al. 2009, in the United States). Decreased empathic responses, in turn, were found to be responsible for this decrement, thus supporting the mediating role of empathy in the relation between sexually objectifying media and bystander intervention. Therefore, sexually objectifying media may lead potential perpetrators and bystanders to manifest reduced empathy with women, thus increasing the likelihood of harassing behaviors and reducing helping responses.

It is worth noting that in the study we briefly described Cogoni et al. (2018a, 2018b) have also shown that reduced empathy toward sexually objectified women at the neural level was not related with individuals' personal levels of dispositional empathy, hostile or benevolent sexism, or social dominance attitudes. Instead, it was associated with dehumanization. Both male and female participants dehumanized the sexually objectified women, rating them as less intelligent and less agentic than non-sexually objectified targets. These findings support the evidence that empathy is undermined when the target is dehumanized and seen more as an object than as a complete human being experiencing feelings and concerns (Čehajić et al. 2009; see also Page and Pina 2015).

Similarly, Quinn (2002, in the United States) interviewed a sample of employed men and women to investigate gender differences in interpreting sexual harassment incidents at work. The author found that men often failed to recognize behaviors such as sexual body evaluation of employed women as instances of sexual harassment because of a combination of sexual objectification/dehumanization and decreased empathy with their female coworkers. Moreover, in a study by Holland and Haslam (2016) college students were first exposed to real advertisements depicting sexually objectified versus non-sexually objectified female adolescents and then learned that the young women portrayed in the advertisements had been harmed. Results revealed lower attributions of personhood, reduced concern toward the victims, more perceived victims' responsibility, and more negative attitudes toward helping the victims in the sexually objectifying than non-sexually objectifying condition. Overall, the evidence we reviewed suggests that dehumanization may contribute to account for the link between the construct of women as sexual objects, disruption of empathic resonance toward women, and increased engagement in sexual harassment, as well as reduced bystander intervention.
Sexually Objectifying Media $\rightarrow$ Shift in Gender Norms

What specific norms may be influenced by exposure to sexually objectifying media and how do these norms affect sexual harassment? Particularly central in this context may be traditional masculinity and femininity ideologies (Levant et al. 1992; Mahalik et al. 2005), namely the constellation of social norms, behavioral standards, and expectations associated with traditional male and female roles. Mass media may act as a sounding board for those specific masculine and feminine norms that prescribe women to be silent, submissive, compliant, dependent on men, sexy, and always available sexual partners, and men to be dominant, sex driven, and fearful of commitment (Sprecher and McKinney 1993; see also Preddie and Biernat 2020).

Not surprisingly, the belief system surrounding traditional masculinity has been found to be linked consistently to men's sexual harassment, rape-supportive attitudes, violence against women, and sexual assault (see McDermott et al. 2015; Murnen et al. 2002, for reviews). For example, conformity to masculine norms of being playboys (according to which men are sexually promiscuous) and having power over women (i.e., the belief that men should control women) are related to men's tendencies of gazing at, inspecting, and evaluating women's bodies, as well as to higher levels of unwanted sexual advances toward women (Mikorski and Szymanski 2017). At the same time, women who endorse traditional feminine norms typically show decreased sexual assertiveness (Curtin et al. 2011), invest more in their appearances (Kling et al. 2017), and are more likely to enjoy being sexualized, to engage in self-objectification (Hurt et al. 2007; Liss et al. 2011), and to perceive sexual harassment as a normative male-female sexual behavior (Jensen and Gutek 1982).

Extending these findings, the Media-Induced Sexual Harassment framework postulates that the construct of women as sexual objects activated by exposure to sexually objectifying media promotes a shift in gender norms, thus enhancing viewers' endorsement of norms associated with men' and women's roles. Consistently, men's greater consumption of magazines, television programs (e.g., situation comedies, dramas, sports programs), movies, video games, and internet sites is associated with stronger endorsement of traditional masculine norms (Giaccardi et al. 2016, in the United States; Scharrer and Blackburn 2018, in the United States). For example, exposure to music videos and TV programs has been found to be linked to greater endorsement of masculinity norms according to which men are sexually dominant and women are sexual objects, as well as to increased objectification of women's bodies, even among male adolescents (Rousseau et al. 2019, in Belgium).

Moreover, in a longitudinal study, Wright and Tokunaga (2015, in the United States) found that men's regular exposure to sexually objectifying media was related to greater 
conformity to the masculine norm of non-relational attitudes toward sex. Results also demonstrated that recent exposure to similar media contents had immediate strengthening effects on the same norms among men who viewed sexually objectifying media less frequently. Importantly, such effects persisted for two days. In a similar vein, greater exposure to or involvement with sexually objectifying media, such as soap operas, talk shows, prime-time programs, and music videos, is related with women's greater endorsement of both traditional femininity and masculinity ideologies (Blackburn and Scharrer 2019, in the United States; Scharrer and Blackburn 2018, in the United States; Ward and Friedman 2006, in the United States), in particular with the beliefs that women are sex objects and that men are sex-driven, lack relationship skills, and are fearful of commitment (Kim and Ward 2004, in the United States; Ward 2002, in the United States).

As postulated by the Media-Induced Sexual Harassment framework, higher conformity to traditional masculine and feminine norms due to exposure to sexually objectifying media should lead to an increase in sexual harassment. Consistently, after exposure to a sexually objectifying TV clip (vs. control programs and TV clips showing non-objectified professional women), male participants manifested not only increased conformity to traditional masculinity norms regarding non-relational attitudes toward sex, dominance, and aggression, but also greater gender-harassing behavior (Galdi et al. 2014, in Italy). Results also revealed that the masculine norm of non-relational attitudes toward sex mediated the relation between experimental condition and participants' genderharassing behavior (see also Guizzo and Cadinu 2020, in Italy, for similar results with gender attitudes as mediator). A similar norm shift was observed among video game players (Gabbiadini et al. 2016, in Italy). Playing sexually objectifying video games increased participants' endorsement of masculine norms, especially among male participants who strongly identified with the game character. Masculine norms, in turn, led to reduced empathy toward female victims of violence.

To summarize, evidence shows that exposure to sexually objectifying media leads to shifts in gender norms that establish which behaviors are appropriate for men and women. Such norms, in turn, have been found not only to encourage proclivity to sexual harassment, but also to decrease empathy with victims of sexual violence, thus pointing to a possible relation between norms and empathy as additional mechanism responsible both for engagement in harassing behaviors and reduced bystander intervention. No known study to date, however, has investigated the link between sexually objectifying media, conformity to traditional gender-role norms, and women's tolerance for sexual harassment. Nonetheless, data suggest that traditional feminine norms dictate how women who have been sexually harassed are going to feel about the incident. If harassed women endorse traditional feminine beliefs, they are more likely to blame themselves for the incident, to believe that victims of sexual harassment have provoked advances, have done something to bring them about, and could do something to prevent them (Jensen and Gutek 1982, in the United States). Importantly, harassed women who endorse traditional feminine norms are also less likely to report the incident to someone in authority (Jensen and Gutek 1982). Traditional feminine norms, therefore, may lead women to assign more responsibility to themselves and to other women in general for incidents of sexual harassment, as well as to be less likely to react and seek help.

\section{Discussion}

Sexual harassment is both a form of aggression against women and a form of gender discrimination, and it represents a serious and widespread social problem (Stop Street Harassment 2018). With the present work, we aimed at contributing to the current conversation about its causes by synthesizing the existing empirical evidence on the link between sexually objectifying media and sexual harassment into the novel and integrative Media-Induced Sexual Harassment framework. We believe that the present framework extends the understanding of this growing body of research in multiple ways.

First, for the first time the overarching Media-Induced Sexual Harassment framework incorporates all three target groups involved in sexual harassment, namely perpetrator, victim, and bystander. It also shows that sexually objectifying media may represent a crucial cultural factor that encourages sexual harassment (a) increasing perpetrators' proclivity to sexually harass, (b) encouraging victims' tolerance for harassing behaviors, and (c) discouraging bystanders from intervening. In the last two decades a great deal of research has examined the effects of sexually objectifying media on objectification of women and women's self-objectification (e.g., Ward 2016). Extending these findings to the issue of sexual harassment, our reviewed evidence demonstrates that exposure to sexually objectifying media affects not only women's self-perceptions and behavior, but also the way women are perceived and treated by others.

Second, a notable facet of the Media-Induced Sexual Harassment framework is that it speaks to how sexually objectifying media lead to sexual harassment. We have demonstrated that sexually objectifying media implicitly set two cultural standards: (a) how women should behave and look (i.e., sexy, available, and good-looking) and (b) how women can be treated by others (as bodies that exist for the pleasure of others). Drawing from cognitive theories focusing on schema activation and accessibility (see Fiske and Taylor 1991) and on script-based models of media effects (Wright 2011), the Media-Induced Sexual Harassment framework postulates that 
these two cultural standards inform, and even may help to create, the construct of women as sexual objects. The evidence reviewed in the present work shows that the accessibility of the construct of women as sexual object after exposure to sexually objectifying media may result not only in negative attitudes and emotions, but also (through dehumanization, disruption of empathic resonance, and shift in gender norms) in actual harassing behaviors toward women, greater acceptance by women of sexual harassment, and reduced bystander intervention in subsequent unrelated contexts.

Third, the Media-Induced Sexual Harassment framework can be relevant for explaining media connections to sexual violence in general. For example, many studies we reviewed in the present work indicate that exposure to sexually objectifying media may increase both women's and men's rape myth acceptance (Driesmans et al. 2015; Reichl et al. 2018), men's engagement in sexual aggression (Lanis and Covell 1995), and women's acceptance of dating violence (Johnson et al. 1995). Moreover, research has established that reduction of women to sexual objects, dehumanization, disruption of emphatic resonance, and shifts in gender norms are mechanisms involved in all forms of violence against women, including rape and sexual assault (Beech et al. 2006; Hlavka 2014; Rudman and Mescher 2012).

Finally, according to current approaches, the concept of sexual violence includes a range of behaviors that are linked to one another and escalate in severity (Kelly 1987; Leidig 1992; Osborne 1995; Stout 1991). At one end of this continuum are sexually violent behaviors, such as rape, sexual assault, and criminal sexual contact; at the other end are those behaviors, often culturally accepted, of gender harassment and unwanted sexual attention. Showing that sexually objectifying media may converge in normalizing harassing behaviors, the evidence we reviewed in the present paper demonstrates that sexually objectifying media may help to create a culture that not only enables the existence of sexual harassment but also may ultimately support and tolerate more severe forms of gender violence.

\section{Practice Implications}

By improving our understanding of sexual harassment and sexually objectifying media as a factor that contributes to its perpetration, the Media-Induced Sexual Harassment framework has the potential to aid in the development of more effective prevention and education efforts, as well as to inform interventions and social policy. First, evidence shows that media may exert a role especially because they affect viewers' attitudes, emotions, and behaviors in subtle ways. Nonetheless, it is possible to control these automatic influences. Researchers have identified three steps that could enable individuals to gain conscious control over automatic behavioral and attitudinal responses: (a) awareness of the influence or the possibility of influence, (b) motivation to control the influence and response, and (c) mental capacity to engage in the control process (Bargh 1989; Wegner 1994). These suggestions imply that if women and men are educated to view sexually objectifying media with a more critical, aware eye, as opposed to simply allowing them to permeate their leisure and work lives, the effects of sexually objectifying media on sexual harassment can be reduced.

Importantly, the research we reviewed in the present paper shows that not only adults', but also adolescents' and children's, attitudes, norms, and behaviors can be affected by exposure to sexually objectifying media. Therefore, schoolbased media literacy programs should be implemented to teach critical viewing skills, to enable youngsters to detect objectifying contents, and to raise awareness of the consequences. When carried out, such programs have been shown to be effective (e.g., Choma et al. 2007; see also Liao et al. 2020; Rodgers et al. 2019). Also parents represent important targets for interventions. For example, parents may be educated to discuss with children the subtle sexually objectifying acts exhibited in the media and may be encouraged to promote the development of positive and egalitarian gender-related attitudes and behaviors among their sons and daughters.

It is worth noting that not only may media be one of the causes of the problem, but they also can be the source of possible solutions. For example, media-sensitizing messages against sexual objectification of women have proven to be successful both in motivating women to take action and fight for gender equality (Guizzo et al. 2017) and in decreasing men's perpetration of sexual harassment (Guizzo and Cadinu 2020). Therefore, media promoting a critical and active rather than passive consumption can represent valuable tools that media specialists should employ. At the same time, advertising and media makers should also consider other strategies to attract viewers and consumers rather than presenting women in sexually objectifying fashions. Ironically, such degrading portrayals not only damage our society at large, as we discussed previously, but also may represent a counterproductive strategy to sell products. For example, exposure to sexually objectifying (vs. neutral) ads did not increase men's willingness to purchase the products promoted but they did decrease women purchase intentions (Gramazio et al. 2020; see also Bushman 2005; Zawisza et al. 2018). Thus, the commercial ideology behind them may ultimately prove to be counter-productive.

Another crucial intervention should be to educate women about self-objectification and strategies to avoid the experience and consequences of it. These strategies may include increasing self-awareness as well as developing awareness of the dissonance between the reality of actual women and the contrived women portrayed in the media, the latter of whom convey not only an unrealistic, but also a demeaning 
and degrading female representation (see Tylka and Augustus-Horvath 2011, for a review).

Finally, by linking media culture, social norms, and sexual harassment, the Media-Induced Sexual Harassment framework suggests that restrictive versus permissive norms regarding sexual harassment may be communicated through media and attests to the responsibility of the media industry in creating a cultural environment that can be either derogatory or respectful of individuals' gender identity. Practitioners from a wide range of professions (including teachers, counselors, game developers, journalists, and advertisers) should be aware that media represent a powerful vehicle for sexualized social norms by (a) providing legitimacy to potential male harassers, (b) increasing tolerance of women and girls for sexual harassment, and (c) discouraging bystanders from intervening because they are unable to promptly recognize sexual harassment.

\section{Research Agenda}

Despite the impressive set of scholarship we summarized here on the link between sexually objectifying media and sexual harassment, some questions remain, and additional research is needed in various areas. We will therefore conclude by pointing out some directions and topics for future research, along with important suggestions to further test the tenets of the Media-Induced Sexual Harassment framework.

\section{Web and Social Media}

Sexually objectifying media include not only "traditional mass media" (e.g., magazines, film, television, music videos, video games, internet sites), but also recent advances in internet technologies that have led to the revolutionary new trend represented by social media (e.g., applications such as YouTube, Facebook, Instagram, Second Life, Tinder, TikTok, and Twitter). The participatory nature of social media entails an open forum for information exchange, thus widening the dissemination of episodes, images, and words that sexually objectify women. To date, however, research on the effects of sexually objectifying contents via social media on sexual harassment and sexual violence in general is still in its very early stages (see Felmlee et al. 2020; Gramazio et al. 2019; Spaccatini et al. 2019, for some early research). Therefore, although the Media-Induced Sexual Harassment framework encompasses the role played by the full extent of sexually objectifying media, most studies we reviewed in in the present article focused on "traditional media." We hope future research will expand the emerging evidence on the role played by sexually objectifying contents via social media and the web in general on sexual harassment.

\section{Weak Connections}

As shown in Fig. 1, the Media-Induced Sexual Harassment framework includes three mechanisms of cognitive, emotional, and normative nature through which the concept of women as sexual objects activated by exposure to sexually objectifying media leads to sexual harassment: dehumanization, disruption of empathic resonance, and shift in gender norms. Specifically, all three mechanisms mediate the relation between sexually objectifying media and perpetrators' engagement in harassing behaviors, as well as bystander intervention. However, as pointed out in Table 2, no known research to date has directly investigated the links among exposure to sexually objectifying media, dehumanization of women, and bystander intervention. Similarly, more research is needed to support the links among exposure to sexually objectifying media, empathy toward women, and sexual harassment proclivity. Moreover, strong evidence indicates that exposure to sexually objectifying media enhances consumers' endorsement of traditional masculine and feminine norms (Blackburn and Scharrer 2019; Wright and Tokunaga 2015) and that endorsement of gender norms reduces empathy with victims of violence (Gabbiadini et al. 2016). However, research testing the path from shift in gender norms to bystander intervention is still absent.

Turning to women as potential victims, the Media-Induced Sexual Harassment framework postulates that the mechanisms responsible for victims' increased tolerance for sexual harassment are (self-)dehumanization and shift in gender norms. Concerning the latter mechanism, findings show that exposure to sexually objectifying media is related with women's greater endorsement of both traditional femininity and masculinity ideologies (Scharrer and Blackburn 2018). However, no known study has directly tested these links in their entirety - that is, whether shifts in gender norms explain the relation between exposure to sexually objectifying media and women's tolerance for sexual harassment.

Further, the Media-Induced Sexual Harassment framework postulates interconnections among the three cognitive, affective, and normative mechanisms that research has not yet openly addressed. For example, a path between dehumanization and disruption of empathic resonance (Cogoni et al. 2018a, 2018b; Holland and Haslam 2016) should help to better explain relations between sexually objectifying media and both engagement in harassing behavior and bystander intervention. Therefore, we strongly encourage future work to address all these important issues. A goal of future studies should be also to expand the Media-Induced Sexual Harassment framework by exploring additional potential interconnections among the three proposed mechanisms, as well as testing whether other cognitive and/or affective processes may account for the link among sexually objectifying media, the construct of women as sexual object, and sexual harassment. 


\section{Multiple Meanings and Viewers' Skills}

In the present work we exclusively focused on the negative effects of exposure to sexually objectifying media depicting submissive, compliant, and sexy women. However, it is not rare to run across media content in which women are both strong and sexually objectified. For example, the popular TV series "Sex and the City" revolved around the lives of four professional and independent women who, nonetheless, paid great attention to their appearance and sex appeal. It is very likely that these portrayals convey multiple meanings to viewers. To our knowledge, however, no known study has investigated how consumers interpret such messages, whether they actually associate multiple meanings to them, and, importantly, what effects these messages may have on consumers' attitudes and behaviors.

In addition to increasing awareness of alternative and multiple meanings, researchers are encouraged to investigate the issue of how sexually objectifying content is interpreted by consumers. Not all consumers interpret the same content in the same way (Brown 2000; Livingstone 1990) and not all consumers accept the messages presented; some may reject and resist them. If not all consumers are negatively affected by sexually objectifying media, what skills do these consumers have to face the potential negative effects of exposure to sexually objectifying media? It is possible that consumers with lower endorsement of masculine and/or feminine ideologies, with more advanced critical thinking skills, or with greater media literacy may be better able to reject sexually objectifying contents and to resist their influence. In general, therefore, a better understanding is needed of how and when sexually objectifying content is accepted, critiqued, and/or rejected.

\section{Ethnic Minorities}

It is also critical to think more carefully about how sexual objectifying media intersect with various social identities of women. For example, the research we reviewed here mainly tested the effects of sexually objectifying media portrayals of White/European or American women on samples of White/ European or American consumers, whereas ethnic minorities have been largely ignored, both as targets and as consumers. Therefore, one might wonder whether women and men of other races/ethnicities may associate different meanings to these media messages. Concerning race/ethnicity, however, the available evidence is still scarce. Nonetheless, some studies indicate that sexual objectification in the media may target women and girls of all ethnicities (Aubrey and Frisby 2011; McDade-Montez et al. 2017; Prieler and Centeno 2013), even though some cross-cultural differences have also been reported (see Frith et al. 2005; Nelson and Paek 2005).

Furthermore, exposure to and identification with portrayals of sexually objectified Black women in the media has been found to be linked with increased importance of appearance and physical attractiveness among Black female adolescents (Gordon 2008; but see Schooler et al. 2004, for null results on body image concerns). Importantly, exposure to sexually objectifying (vs. neutral) music videos may increase not only White, but also Black, female and male adolescents' acceptance of rape myths and interpersonal violence, as well as their endorsement of the belief that women are sexual objects and men are sex-driven (Johnson et al. 1995; Kalof 1999; Ward et al. 2005). Although this existing research suggests that at least some tenets of the Media-Induced Sexual Harassment framework might be extended to other ethnicities, further extensive research is needed to get a complete picture.

\section{Sexual Identity}

Future endeavors should also investigate whether the postulates of the Media-Induced Sexual Harassment framework may vary as a function of women's sexual orientation. Some preliminary evidence shows that lesbian women report the same levels of harassing experiences and similar levels of self-objectification as heterosexual women (Hill and Fischer 2008; see also Kozee and Tylka 2006). Thus, there is reason to believe that sexually objectifying media increase the likelihood of men's harassment of women independent of the sexual orientation of the female victim. However, it remains unclear whether the same pattern holds for the relation between sexually objectifying media and women's acceptance of being harassed, which may well vary as a function of their sexual orientation.

\section{Sexual Harassment of Men}

The Media-Induced Sexual Harassment framework focuses on media effects on sexual harassment only considering women as the potential victims and men as the potential perpetrators. Although men are overall much less likely to become victims of sexual harassment, they are the most common target of same-gender harassment (European Union Agency for Fundamental Rights 2012; McDonald and Charlesworth 2016). In these cases, the motivation behind sexual harassment seems to be gender-identity protection, given that it is often used as a weapon against those men who violate gender norms (Maass et al. 2013). Portrayals of sexually objectified men are increasing in prevalence (Hatton and Trautner 2011) but, unlike sexually objectified women, sexually objectified men are typically depicted as strong, dominant, and with a muscular body. It is likely, therefore, that exposure to these images increases men's sexual harassment toward other men who do not comply to these masculine norms. However, it is difficult to believe that exposure to sexually objectified portrayals of men could explain women's sexual harassment of men, although this remains an interesting possibility to be investigated by future research. 


\section{Longitudinal Designs}

From a methodological point of view, many studies summarized in this review used correlational designs that are open to different interpretations. Sexually objectifying media may affect attitudes, beliefs, and behaviors or, instead, consumers may seek out content that validates their current attitudes and beliefs. Nonetheless, many of these correlational studies have experimental counterparts, as we reported in the present review. Yet, these experimental studies examined short-term effects of sexually objectifying media after only a few minutes of exposure to such content, thus raising potential concerns about their external validity and demand characteristics. Given that sexually objectifying contents are commonplace in the media, we believe that results of these studies might even represent an underestimation of actual (daily) exposure to sexually objectifying media. At the same time, the degree to which viewers' attitudes and expectations are affected by media exposure are likely to vary, for example depending on age and experience. To date, however, very few studies have employed longitudinal designs to explore whether and how the media's influence changes over time. Many scholars have concluded that media certainly exert an influence on viewers (e.g., Wright 2011) and the evidence we reviewed here suggests that sexually objectifying media do, indeed, affect sexual harassment. Nonetheless, to draw firm conclusions more longitudinal work is needed.

\section{Conclusions}

The recent \#MeToo movement has helped raising awareness about sexual harassment. However, to implement effective intervention strategies aimed at tackling sexual harassment, not only is it necessary to acknowledge its prevalence, but also action is required to clearly identify its causes. Taking into account three perspectives simultaneously [i.e., the perpetrator's, the victim's, and bystander(s)], as well as integrating several lines of research, the Media-Induced Sexual Harassment framework offers an original scheme for explaining how sexually objectifying media lead to sexual harassment and also shows that media contents matter. We therefore hope that research within this framework will continue to grow.

Acknowledgements The authors thank Anne Maass for her invaluable helpful feedback on a draft of the present manuscript.

Funding Open access funding provided by Università degli Studi della Campania Luigi Vanvitelli within the CRUI-CARE Agreement. Our work was supported by PRIN grant number 20123X2PXT_003 (2012) from the Italian Ministry of Education, University and Research.

\section{Compliance with Ethical Standards}

This manuscript complies with guidelines of the 6th edition Publication Manual of the American Psychological Association, including the provisions under the headings "Duplicate and Piecemeal Publication of Data" and "Alerting the Editor."

Open Access This article is licensed under a Creative Commons Attribution 4.0 International License, which permits use, sharing, adaptation, distribution and reproduction in any medium or format, as long as you give appropriate credit to the original author(s) and the source, provide a link to the Creative Commons licence, and indicate if changes were made. The images or other third party material in this article are included in the article's Creative Commons licence, unless indicated otherwise in a credit line to the material. If material is not included in the article's Creative Commons licence and your intended use is not permitted by statutory regulation or exceeds the permitted use, you will need to obtain permission directly from the copyright holder. To view a copy of this licence, visit http://creativecommons.org/licenses/by/4.0/.

\section{References}

American Psychological Association. (2007). Report of the APA task force on the sexualization of girls. Retrieved from http://www.apa. org/pi/women/programs/girls/report-full.pdf. Accessed Feb 2016.

Armstrong, E. A., Hamilton, L., \& Sweeney, B. (2006). Sexual assault on campus: A multilevel, integrative approach to party rape. Social Problems, 53, 483-499. https://doi.org/10.1525/sp.2006.53.4.483.

Arnett, J. J. (2002). The sounds of sex: Sex in teens' music and music videos. In J. D. Brown, K. Walsh-Childers, \& J. Steele (Eds.), LEA's communication series. Sexual teens, sexual media: Investigating media's influence on adolescent sexuality (pp. 253-264). Hillsdale: Erlbaum.

Aubrey, J. S., \& Frisby, C. M. (2011). Sexual objectification in music videos: A content analysis comparing gender and genre. Mass Communication and Society, 14, 475-501. https://doi.org/10.1080/ 15205436.2010.513468.

Aubrey, J. S., Hopper, K. M., \& Mbure, W. G. (2011). Check that body! The effects of sexually objectifying music videos on college men's sexual beliefs. Journal of Broadcasting \& Electronic Media, 55, 360-379. https://doi.org/10.1080/08838151.2011.597469.

Avina, C., \& O'Donohue, W. (2002). Sexual harassment and PTSD: Is sexual harassment diagnosable trauma? Journal of Traumatic Stress: Official Publication of The International Society for Traumatic Stress Studies, 15, 69-75. https://doi.org/10.1023/A: 1014387429057.

Awasthi, B. (2017). From attire to assault: Clothing, objectification, and de-humanization. A possible prelude to sexual violence? Frontiers in Psychology, 8, 338. https://doi.org/10.3389/fpsyg.2017.00338.

Baldissarri, C., Andrighetto, L., Gabbiadini, A., Valtorta, R. R., Sacino, A., \& Volpato, C. (2019). Do self-objectified women believe themselves to be free? Sexual objectification and belief in personal free will. Frontiers in Psychology, 10, 1867. https://doi.org/10.3389/ fpsyg.2019.01867.

Bandura, A. (1999). Moral disengagement in the perpetration of inhumanities. Personality and Social Psychology Review, 3, 193-209. https://doi.org/10.1207/s15327957pspr0303_3.

Bandura, A. (2001). Social cognitive theory of mass communication. Media Psychology, 3, 265-299. https://doi.org/10.1207/ S1532785XMEP0303 03. 
Banyard, V. L. (2011). Who will help prevent sexual violence: Creating an ecological model of bystander intervention. Psychology of Violence, 1, 216-229. https://doi.org/10.1037/a0023739.

Bargh, J. A. (1989). Conditional automaticity: Varieties of automatic influence in social perception and cognition. In J. S. Uleman \& J. A. Bargh (Eds.), Unintended thought (pp. 3-51). New York: Guilford Press.

Bargh, J. A. (1996). Automaticity in social psychology. In E. T. Higgins \& A. W. Kruglanski (Eds.), Social psychology: Handbook of basic principles (pp. 169-183). New York: Guilford Press.

Bargh, J. A., Raymond, P., Pryor, J. B., \& Strack, F. (1995). Attractiveness of the underling: An automatic power $\rightarrow$ sex association and its consequences for sexual harassment and aggression. Journal of Personality and Social Psychology, 68, 768-781. https:// doi.org/10.1037//0022-3514.68.5.768.

Bargh, J. A., Chen, M., \& Burrows, L. (1996). Automaticity of social behavior: Direct effects of trait construct and stereotype activation on action. Journal of Personality and Social Psychology, 71, 230 244. https://doi.org/10.1037/0022-3514.71.2.230.

Bartky, S. L. (1990). Femininity and domination: Studies in the phenomenology of oppression. New York: Routledge.

Bartling, C. A., \& Eisenman, R. (1993). Sexual harassment proclivities in men and women. Bulletin of the Psychonomic Society, 31, 189-192. https://doi.org/10.3758/BF03337321.

Beech, A. R., Ward, T., \& Fisher, D. (2006). The identification of sexual and violent motivations in men who assault women: Implication for treatment. Journal of Interpersonal Violence, 21, 1635-1653. https://doi.org/10.1177/0886260506294242.

Bell, K. M., \& Naugle, A. E. (2008). Intimate partner violence theoretical considerations: Moving towards a contextual framework. Clinical Psychology Review, 28, 1096-1107. https://doi.org/10.1016/j.cpr. 2008.03.003.

Berkowitz, L., \& Rogers, K. H. (1986). A priming effect analysis of media influences. In J. Bryant \& D. Zillmann (Eds.), Perspectives on media effects (pp. 57-81). Hillsdale: Erlbaum.

Bernard, P., Gervais, S. J., Allen, J., Campomizzi, S., \& Klein, O. (2012). Integrating sexual objectification with object versus person recognition: The sexualized-body-inversion hypothesis. Psychological Science, 23, 469-471. https://doi.org/10.1177/0956797611434748.

Bernard, P., Gervais, S. J., Allen, J., \& Klein, O. (2013). Perceptual determinants are critical, but they don't explain everything: A response to Tarr (2013). Psychological Science, 24, 1071-1073. https://doi.org/10.1177/0956797612474672.

Bernard, P., Legrand, S., \& Klein, O. (2018). From bodies to blame: Exposure to sexually objectifying media increases tolerance toward sexual harassment. Psychology of Popular Media Culture, 7, 99112. https://doi.org/10.1037/ppm0000114.

Blackburn, G., \& Scharrer, E. (2019). Video game playing and beliefs about masculinity among male and female emerging adults. Sex Roles, 80, 310-324. https://doi.org/10.1007/s11199-018-0934-4.

Bodenhausen, G. V., \& Macrae, C. N. (1998). Stereotype activation and inhibition. In R. S. Wyer (Ed.), Stereotype activation and inhibition: Advances in social cognition (Vol. XI, pp. 1-52). Hillsdale: Erlbaum.

Bowes-Sperry, L., \& O’Leary-Kelly, A. M. (2005). To act or not to act: The dilemma faced by sexual harassment observers. Academy of Management Review, 30, 288-306. https://doi.org/10.5465/amr. 2005.16387886.

Brown, J. D. (2000). Adolescents' sexual media diets. Journal of Adolescent Health, 27, 35-40. https://doi.org/10.1016/S1054$139 \mathrm{X}(00) 00141-5$.

Bryant, J., \& Oliver, M. B. (2009). Media effects: Advances in theory and research. New York: Routledge.

Burgess, M. C. R., \& Burpo, S. (2012). The effect of music videos on college students perceptions of rape. College Student Journal, 46, 748-763. Retrieved from https://www.questia.com/library/journal/
1G1-312618213/the-effect-of-music-videos-on-college-studentsperceptions. Accessed Apr 2018.

Burn, S. M. (2009). A situational model of sexual assault prevention through bystander intervention. Sex Roles, 60, 779-792. https:// doi.org/10.1007/s11199-008-9581-5.

Bushman, B. J. (1995). Moderating role of trait aggressiveness in the effects of violent media on aggression. Journal of Personality and Social Psychology, 69, 950-960. https://doi.org/10.1037/00223514.69.5.950.

Bushman, B. J. (2005). Violence and sex in television programs do not sell products in advertisements. Psychological Science, 16, 702708. https://doi.org/10.1111/j.1467-9280.2005.01599.x.

Campbell, J. (2002). Health consequences of intimate partner violence. Lancet, 359, 1331-1336. https://doi.org/10.1016/S0140-6736(02) 08336-8.

Cantisano, G. T., Domínguez, J. M., \& Depolo, M. (2008). Perceived sexual harassment at work: Meta-analysis and structural model of antecedents and consequences. The Spanish Journal of Psychology, 11, 207-218. https://doi.org/10.1017/S113874160000425X.

Capaldi, D. M., Dishion, T. J., Stoolmiller, M., \& Yoerger, K. (2001). Aggression toward female partners by at-risk young men: The contribution of male adolescent friendships. Developmental Psychology, 37, 61-73. https://doi.org/10.1037/0012-1649.37.1.61.

Caravita, S. C. S., Di Blasio, P., \& Salmivalli, C. (2009). Unique and interactive effects of empathy and social status on involvement in bullying. Social Development, 18, 140-163. https://doi.org/10. 1111/j.1467-9507.2008.00465.x.

Čehajić, S., Brown, R., \& González, R. (2009). What do I care? Perceived ingroup responsibility and dehumanization as predictors of empathy felt for the victim group. Group Processes \& Intergroup Relations, 12, 715-729. https://doi.org/10.1177/1368430209347727.

Chen, S., \& Andersen, S. M. (1999). Relationships from the past in the present: Significant-other representations and transference in interpersonal life. Advances in Experimental Social Psychology, 31, 123-190. https://doi.org/10.1016/S0065-2601(08)60273-7.

Chen, Z., Teng, F., \& Zhang, H. (2013). Sinful flesh: Sexual objectification threatens women's moral self. Journal of Experimental Social Psychology, 49, 1042-1048. https://doi.org/10.1016/j.jesp.2013.07. 008.

Choma, B. L., Foster, M. D., \& Radford, E. (2007). Use of objectification theory to examine the effects of a media literacy intervention on women. Sex Roles, 56, 581-590. https://doi.org/10.1007/s11199007-9200-x.

Cialdini, R. B., \& Trost, M. R. (1998). Social influence: Social norms, conformity, and compliance. In D. T. Gilbert, S. T. Fiske, \& G. Lindzey (Eds.), The handbook of social psychology (Vol. 2, pp. 151-192). New York: McGraw-Hill.

Cikara, M., Eberhardt, J. L., \& Fiske, S. T. (2011). From agents to objects: Sexist attitudes and neural responses to sexualized targets. Journal of Cognitive Neuroscience, 23, 540-551. https://doi.org/ 10.1162/jocn.2010.21497.

Civile, C., \& Obhi, S. S. (2016). Power, objectification, and recognition of sexualized women and men. Psychology of Women Quarterly, 40, 199-212. https://doi.org/10.1177/0361684315604820.

Cogoni, C., Carnaghi, A., \& Silani, G. (2015). Can we empathize with objectified women? How the perception of others shapes our feeling toward them. In P. Bernardis, C. Fantoni, \& W. Gerbino (Eds.), TSPC2015: Proceedings of the Trieste symposium on perception and cognition, November 13rd 2015 (pp. 43-44). Trieste: EUT

Cogoni, C., Carnaghi, A., Mitrovic, A., Leder, H., Fantoni, C., \& Silani, G. (2018a). Understanding the mechanisms behind the sexualizedbody inversion hypothesis: The role of asymmetry and attention biases. PLoS One, 13, e0193944. https://doi.org/10.1371/journal. pone.0193944. 
Cogoni, C., Carnaghi, A., \& Silani, G. (2018b). Reduced empathic responses for sexually objectified women: An fMRI investigation. Cortex, 99, 258-272. https://doi.org/10.1016/j.cortex.2017.11.020.

Conley, T. D., \& Ramsey, L. R. (2011). Killing us softly? Investigating portrayals of women and men in contemporary magazine advertisements. Psychology of Women Quarterly, 35, 469-478. https://doi. org/10.1177/0361684311413383.

Council of Europe. (2011). Convention on preventing and combating violence against women and domestic violence and its explanatory memorandum. Council of Europe Treaty Series - No. 210. Retrieved from https://rm.coe.int/168008482e. Accessed Sept 2012.

Crocker, J., Fiske, S. T., \& Taylor, S. E. (1984). Schematic bases of belief change. In J. R. Eiser (Ed.), Attitudinal judgment (pp. 197-226). New York: Springer.

Curtin, N., Ward, L. M., Merriwether, A., \& Caruthers, A. (2011). Femininity ideology and sexual health in young women: A focus on sexual knowledge, embodiment, and agency. International Journal of Sexual Health, 23, 48-62. https://doi.org/10.1080/ 19317611.2010 .524694$.

Dall'Ara, E., \& Maass, A. (2000). Studying sexual harassment in the laboratory: Are egalitarian women at higher risk? Sex Roles, 41, 681-704. https://doi.org/10.1023/A:1018816025988.

Decety, J., \& Jackson, P. L. (2004). The functional architecture of human empathy. Behavioral and Cognitive Neuroscience Reviews, 3, 406412. https://doi.org/10.1177/1534582304267187.

DeSouza, E. R. (2010). Frequency rates and consequences of peer sexual harassment: Comparing U.S. and international students. In M. A. Paludi (Ed.), Feminism and women's rights worldwide (pp. 195208). Santa Barbara: Praeger.

Dijksterhuis, A., \& van Knippenberg, A. D. (1996). The knife that cuts both ways: Facilitated and inhibited access to traits as a result of stereotype activation. Journal of Experimental Social Psychology, 32, 271-288. https://doi.org/10.1006/jesp.1996.0012.

Dill, K. E., Brown, B. P., \& Collins, M. A. (2008). Effects of exposure to sex-stereotyped video game characters on tolerance of sexual harassment. Journal of Experimental Social Psychology, 44, 14021408. https://doi.org/10.1016/j.jesp.2008.06.002

Driesmans, K., Vandenbosch, L., \& Eggermont, S. (2015). Playing a videogame with a sexualized female character increases adolescents' rape myth acceptance and tolerance toward sexual harassment. Games for Health Journal, 4, 91-94. https://doi.org/10. 1089/g4h.2014.0055.

Eisenberg, N., \& Fabes, R. A. (1990). Empathy: Conceptualization, measurement, and relation to prosocial behavior. Motivation and Emotion, 14, 131-149. https://doi.org/10.1007/BF00991640.

European Commission, Directorate-General for Justice and Consumers. (2016). Special Eurobarometer 449 - Gender-based violence. Retrieved from https://data.europa.eu/euodp/data/dataset/S2115 85_3_449_ENG. Accessed Feb 2018.

European Union Agency for Fundamental Rights. (2012). Survey on fundamental rights of lesbian, gay, bisexual and transgender people in EU. Retrieved from https://fra.europa.eu/en/publications-andresources/data-and-maps/survey-fundamental-rights-lesbian-gaybisexual-and. Accessed Feb 2018.

European Union Agency for Fundamental Rights. (2014). Violence against women: An EU-wide survey. Retrieved from https://fra. europa.eu/en/publication/2014/violence-against-women-eu-widesurvey-main-results-report. Accessed Feb 2018

Fasoli, F., Durante, F., Mari, S., Zogmaister, C., \& Volpato, C. (2018). Shades of sexualization: When sexualization becomes sexual objectification. Sex Roles, 78, 338-351. https://doi.org/10.1007/s11199017-0808-1.

Felmlee, D., Rodis, D. I., \& Zhang, A. (2020). Sexist slurs: Reinforcing feminine stereotypes online. Sex Roles, 83, 16-28. https://doi.org/ 10.1007/s11199-019-01095-z.
Ferris, A. L., Smith, S. W., Greenberg, B. S., \& Smith, S. L. (2007). The content of reality dating shows and viewer perceptions of dating. Journal of Communication, 57, 490-510. https://doi.org/10.1111/j. 1460-2466.2007.00354.x.

Fischer, P., Krueger, J. I., Greitemeyer, T., Vogrincic, C., Kastenmüller, A., Frey, D., ... Kainbacher, M. (2011). The bystander-effect: A meta-analytic review on bystander intervention in dangerous and non-dangerous emergencies. Psychological Bulletin, 137, $517-$ 537. https://doi.org/10.1037/a0023304

Fiske, S. T., \& Linville, P. W. (1980). What does the schema concept buy us? Personality and Social Psychology Bulletin, 6, 543-557. https:// doi.org/10.1177/014616728064006.

Fiske, S. T., \& Taylor, S. E. (1991). Social cognition. New York: McGraw-Hill.

Fitzgerald, L. F., \& Hesson-McInnis, M. (1989). The dimensions of sexual harassment: A structural analysis. Journal of Vocational Behavior, 35, 309-326. https://doi.org/10.1016/0001-8791(89) 90032-8.

Fitzgerald, L. F., Gelfand, M., \& Drasgow, F. (1995a). Measuring sexual harassment: Theoretical and psychometric advances. Basic and Applied Social Psychology, 17, 425-445. https://doi.org/10.1207/ s15324834basp1704_2.

Fitzgerald, L. F., Swan, S., \& Fischer, K. (1995b). Why didn't she just report him? The psychological and legal implications of women's responses to sexual harassment. Journal of Social Issues, 51, 117138. https://doi.org/10.1111/j.1540-4560.1995.tb01312.x.

Fitzgerald, L. F., Drasgow, F., Hulin, C. L., Gelfand, M. J., \& Magley, V. J. (1997). Antecedents and consequences of sexual harassment in organizations: A test of an integrated model. Journal of Applied Psychology, 82, 578-589. https://doi.org/10.1037/0021-9010.82.4. 578.

Foubert, J. D., Brosi, M. W., \& Bannon, R. S. (2011). Pornography viewing among fraternity men: Effects on bystander intervention, rape myth acceptance and behavioral intent to commit sexual assault. Sexual Addiction \& Compulsivity, 18, 212-231. https://doi. org/10.1080/10720162.2011.625552.

Fouts, G., \& Burggraf, K. (2000). Television situation comedies: Female weight, male negative comments, and audience reactions. Sex Roles, 42, 925-932. https://doi.org/10.1023/A:1007054618340.

Fox, J., Ralston, R. A., Cooper, C. K., \& Jones, K. A. (2015). Sexualized avatars lead to women's self-objectification and acceptance of rape myths. Psychology of Women Quarterly, 39, 349-362. https://doi. org/10.1177/0361684314553578.

Fredrickson, B. L., \& Roberts, T.-A. (1997). Objectification theory: Toward understanding women's lived experiences and mental health risks. Psychology of Women Quarterly, 21, 173-206. https://doi.org/10.1111/j.1471-6402.1997.tb00108.x.

Frith, K., Shaw, P., \& Cheng, H. (2005). The construction of beauty: A cross-cultural analysis of women's magazine advertising. Journal of Communication, 55, 56-70. https://doi.org/10.1111/j.1460-2466. 2005.tb02658.x.

Gabbiadini, A., Riva, P., Andrighetto, L., Volpato, C., \& Bushman, B. J. (2016). Acting like a tough guy: Violent-sexist video games, identification with game characters, masculine beliefs, \& empathy for female violence victims. PLoS One, 11, e0152121. https://doi.org/ 10.1371/journal.pone.0152121.

Galdi, S., Maass, A., \& Cadinu, M. (2014). Objectifying media their effect on gender role norms and sexual harassment of women. Psychology of Women Quarterly, 38, 398-413. https://doi.org/10. 1177/0361684313515185.

Galdi, S., Maass, A., \& Cadinu, M. (2017). Defending the victim of sexual harassment: The influence of civil courage and media exposure. Psychology of Women Quarterly, 41, 338-351. https://doi.org/ $10.1177 / 0361684317709770$.

Geer, J. H., Estupinan, L. A., \& Manguno-Mire, G. M. (2000). Empathy, social skills, and other relevant cognitive processes in rapists and 
child molesters. Aggression and Violent Behavior, 5, 99-126. https://doi.org/10.1016/S1359-1789(98)00011-1.

Gervais, S. J., \& Eagan, S. (2017). Sexual objectification: The common thread connecting myriad forms of sexual violence against women. American Journal of Orthopsychiatry, 87, 226-232. https://doi.org/ $10.1037 /$ ort0000257.

Gervais, S. J., Vescio, T. K., Förster, J., Maass, A., \& Suitner, C. (2012). Seeing women as objects: The sexual body part recognition bias. European Journal of Social Psychology, 42, 743-753. https://doi. org/10.1002/ejsp.1890.

Giaccardi, S., Ward, L. M., Seabrook, R. C., Manago, A., \& Lippman, J. (2016). Media and modern manhood: Testing associations between media consumption and young men's acceptance of traditional gender ideologies. Sex Roles, 75, 151-163. https://doi.org/10.1007/ s11199-016-0588-z.

Glascock, J. (2001). Gender roles on prime-time network television: Demographics and behaviors. Journal of Broadcasting \& Electronic Media, 45, 656-669. https://doi.org/10.1207/ s15506878jobem4504_7.

Glick, P., Larsen, S., Johnson, C., \& Branstiter, H. (2005). Evaluations of sexy women in low- and high-status jobs. Psychology of Women Quarterly, 29, 389-395. https://doi.org/10.1111/j.1471-6402.2005. 00238.x.

Glomb, T. M., Munson, L. J., Hulin, C. L., Bergman, M. E., \& Drasgow, F. (1999). Structural equation models of sexual harassment: Longitudinal explorations and cross-sectional generalizations. Journal of Applied Psychology, 84, 14-24. https://doi.org/10.1037/ 0021-9010.84.1.14.

Gordon, M. K. (2008). Media contributions to African American girls' focus on beauty and appearance: Exploring the consequences of sexual objectification. Psychology of Women Quarterly, 32, 245256. https://doi.org/10.1111/j.1471-6402.2008.00433.x.

Grabe, S., Ward, L. M., \& Hyde, J. S. (2008). The role of the media in body image concerns among women: A meta-analysis of experimental and correlational studies. Psychological Bulletin, 134, 460 476. https://doi.org/10.1037/0033-2909.134.3.460.

Gramazio, S., Cadinu, M., Pagliaro, S., \& Pacilli, M. G. (2019). Sexualization of sexual harassment victims reduces bystanders' help: The mediating role of attribution of immorality and blame. Journal of Interpersonal Violence. Advance online publication. https://doi.org/10.1177/0886260518816326

Gramazio, S., Cadinu, M., Guizzo, F., \& Carnaghi, A. (2020). Does sex really sell? Paradoxical effects of sexualization in advertising on product attractiveness and purchase intentions. Sex Roles. Advance online publication. https://doi.org/10.1007/s11199-020-01190-6

Grauerholz, E., \& King, A. (1997). Prime time sexual harassment. Violence Against Women, 3, 129-148. https://doi.org/10.1177/ 1077801297003002003.

Gray, K., Knobe, J., Sheskin, M., Bloom, P., \& Barrett, L. F. (2011). More than a body: Mind perception and the nature of objectification. Journal of Personality and Social Psychology, 101, 1207-1220. https://doi.org/10.1037/a0025883.

Gruber, J., \& Fineran, S. (2016). Sexual harassment, bullying, and school outcomes for high school girls and boys. Violence Against Women, 22, 112-133. https://doi.org/10.1177/1077801215599079.

Guizzo, F., \& Cadinu, M. (2020). Women, not objects: Testing a sensitizing web campaign against female sexual objectification to temper sexual harassment and hostile sexism. Media Psychology. Advance online publication. https://doi.org/10.1080/15213269.2020. 1756338

Guizzo, F., Cadinu, M., Galdi, S., Maass, A., \& Latrofa, M. (2017). Objecting to objectification: women's collective action against sexual objectification on television. Sex Roles, 77, 352-365. https://doi. org/10.1007/s11199-016-0725-8.

Haferkamp, C. J. (1999). Beliefs about relationships in relation to television viewing, soap opera viewing, and self-monitoring. Current
Psychology, 18, 193-204. https://doi.org/10.1007/s12144-9991028-9.

Hansen, C. H., \& Hansen, R. (1988). How rock music videos can change what is seen when boy meets girl: Priming stereotypic appraisal of social interactions. Sex Roles, 19, 287-316. https://doi.org/10.1007/ BF00289839.

Hatton, E., \& Trautner, M. N. (2011). Equal opportunity objectification? The sexualization of men and women on the cover of Rolling Stone. Sexuality and Culture, 15, 256-278. https://doi.org/10.1007/ s12119-011-9093-2.

Heflick, N. A., \& Goldenberg, J. L. (2009). Objectifying Sarah Palin: Evidence that objectification causes women to be perceived as less competent and less fully human. Journal of Experimental Social Psychology, 45, 598-601. https://doi.org/10.1016/j.jesp.2009.02. 008.

Heflick, N. A., \& Goldenberg, J. L. (2014). Seeing eye to body: The literal objectification of women. Current Directions in Psychological Science, 23, 225-229. https://doi.org/10.1177/ 0963721414531599.

Heflick, N. A., Goldenberg, J. L., Cooper, D. P., \& Puvia, E. (2011). From women to objects: Appearance focus, target gender, and perceptions of warmth, morality and competence. Journal of Experimental Social Psychology, 47, 572-581. https://doi.org/10. 1016/j.jesp.2010.12.020.

Hesson-Mcinnis, M. S., \& Fitzgerald, L. F. (1997). Sexual harassment: A preliminary test of an integrative model. Journal of Applied Social Psychology, 27, 877-901. https://doi.org/10.1111/j.1559-1816. 1997.tb00276.x.

Higgins, E. T. (1996). Knowledge activation: Accessibility, applicability, and salience. In E. T. Higgins \& A. W. Kruglanski (Eds.), Social psychology: Handbook of basic principles (pp. 133-168). New York: Guilford Press.

Higgins, E. T., \& Bargh, J. A. (1987). Social cognition and social perception. Annual Review of Psychology, 38, 369-425. https://doi.org/ 10.1146/annurev.ps.38.020187.002101.

Higgins, E. T., \& Brendl, C. M. (1995). Accessibility and applicability: Some "activation rules" influencing judgment. Journal of Experimental Social Psychology, 31, 218-243. https://doi.org/10. 1006/jesp.1995.1011.

Hill, M. S., \& Fischer, A. R. (2008). Examining objectification theory: Lesbian and heterosexual women's experiences with sexual- and self-objectification. The Counseling Psychologist, 36, 745-776. https://doi.org/10.1177/0011000007301669.

Hitlan, R. T., Pryor, J. B., Hesson-McInnis, M. S., \& Olson, M. (2009). Antecedents of gender harassment: An analysis of person and situation factors. Sex Roles, 61, 794-807. https://doi.org/10.1007/ s11199-009-9689-2.

Hlavka, H. R. (2014). Normalizing sexual violence: Young women account for harassment and abuse. Gender \& Society, 28, 337-358. https://doi.org/10.1177/0891243214526468.

Holland, E., \& Haslam, N. (2016). Cute little things: The objectification of prepubescent girls. Psychology of Women Quarterly, 40, 108119. https://doi.org/10.1177/0361684315602887.

Huesmann, L. R. (1986). Psychological processes promoting the relation between exposure to media violence and aggressive behavior by the viewer. Journal of Social Issues, 42, 125-139. https://doi.org/10. 1111/j.1540-4560.1986.tb00246.x.

Huesmann, L. R. (1998). An information processing model for the development of aggression. Aggressive Behavior, 14, 13-24. https://doi. org/10.1002/1098-2337(1988)14:1<13::AID-AB2480140104>3.0. $\mathrm{CO} ; 2-\mathrm{J}$.

Hurt, M., Nelson, J., Turner, D., Haines, M., Ramsey, L., Erchull, M., \& Liss, M. (2007). Feminism: What is it good for? Feminine norms and objectification as the link between feminist identity and clinically relevant outcomes. Sex Roles, 57, 355-363. https://doi.org/10. 1007/s11199-007-9272-7. 
Hust, S. J., Lei, M., Ren, C., Chang, H., McNab, A. L., Marett, E. G., \& Willoughby, J. F. (2013). The effects of sports media exposure on college students' rape myth beliefs and intentions to intervene in a sexual assault. Mass Communication and Society, 16, 762-786. https://doi.org/10.1080/15205436.2013.816737.

Hust, S. J., Rodgers, K. B., Ebreo, S., \& Stefani, W. (2019). Rape myth acceptance, efficacy, and heterosexual scripts in men's magazines: Factors associated with intentions to sexually coerce or intervene. Journal of Interpersonal Violence, 34, 1703-1733. https://doi.org/ $10.1177 / 0886260516653752$.

Ilies, R., Hauserman, N., Schwochau, S., \& Stibal, J. (2003). Reported incidence rates of work-related sexual harassment in the United States: Using meta-analysis to explain reported rate disparities. Personnel Psychology, 56, 607-631. https://doi.org/10.1111/j. 1744-6570.2003.tb00752.x.

Jackson, P. L., Meltzoff, A. N., \& Decety, J. (2005). How do we perceive the pain of others? A window into the neural processes involved in empathy. Neuroimage, 24, 771-779. https://doi.org/10.1016/j. neuroimage.2004.09.006.

Jansma, L. L., Linz, D. G., Mulac, A., \& Imrich, D. J. (1997). Men's interactions with women after viewing sexually explicit films: Does degradation make a difference? Communication Monographs, 64, 1-24. https://doi.org/10.1080/03637759709376402.

Jensen, I. W., \& Gutek, B. A. (1982). Attributions and assignment of responsibility in sexual harassment. Journal of Social Issues, 28, 121-136. https://doi.org/10.1111/j.1540-4560.1982.tb01914.x.

Johnson, J. D., Adams, M. S., Ashburn, L., \& Reed, W. (1995). Differential gender effects of exposure to rap music on African American adolescents' acceptance of teen dating violence. Sex Roles, 33, 597-605. https://doi.org/10.1007/BF01544683.

Johnson, J. D., Olivo, N., Gibson, N., Reed, W., \& Ashburn-Nardo, L. (2009). Priming media stereotypes reduces support for social welfare policies: The mediating role of empathy. Personality and Social Psychology Bulletin, 35, 463-476. https://doi.org/10.1177/ 0146167208329856.

Josephson, W. L. (1987). Television violence and children's aggression: Testing the priming, social script, and disinhibition predictions. Journal of Personality and Social Psychology, 53, 882-890. https://doi.org/10.1037/0022-3514.53.5.882.

Kalof, L. (1999). The effects of gender and music video imagery on sexual attitudes. The Journal of Social Psychology, 139, 378-385. https://doi.org/10.1080/00224549909598393.

Kantor, J., \& Twohey, M. (2017, October 5). Harvey Weinstein paid off sexual harassment accusers for decades. The New York Times. Retrieved from https://www.nytimes.com/2017/10/05/us/harveyweinstein-harassment-allegations.html. Accessed Apr 2018.

Karsay, K., Knoll, J., \& Matthes, J. (2018). Sexualizing media use and self-objectification: A meta-analysis. Psychology of Women Quarterly, 42, 9-28. https://doi.org/10.1177/0361684317743019.

Kelly, L. (1987). The continuum of sexual violence. In J. Hanmer \& M. Maynard (Eds.), Women, violence and social control (pp. 46-60). Atlantic Highlands: Humanities Press International.

Kim, J. L., \& Ward, L. M. (2004). Pleasure reading: Associations between young women's sexual attitudes and their reading of contemporary women's magazines. Psychology of Women Quarterly, 28, 48-58. https://doi.org/10.1111/j.1471-6402.2004.00122.x.

Kim, J. L., Sorsoli, C. L., Collins, K., Zylbergold, B. A., Schooler, D., \& Tolman, D. L. (2007). From sex to sexuality: Exposing the heterosexual script on primetime network television. Journal of Sex Research, 44, 145-157. https://doi.org/10.1080/ 00224490701263660.

Kistler, M. E., \& Lee, M. J. (2009). Does exposure to sexual hip-hop music videos influence the sexual attitudes of college students? Mass Communication and Society, 13, 67-86. https://doi.org/10. 1080/15205430902865336.
Kling, J., Holmqvist Gattario, K., \& Frisén, A. (2017). Swedish women's perceptions of and conformity to feminine norms. Scandinavian Journal of Psychology, 58, 238-248. https://doi.org/10.1111/sjop. 12361.

Kozee, H. B., \& Tylka, T. L. (2006). A test of objectification theory with lesbian women. Psychology of Women Quarterly, 30, 348-357. https://doi.org/10.1111/j.1471-6402.2006.00310.x.

Lambiase, J. (2003). Sex online and in internet advertising. In T. Reichert \& J. Lambiase (Eds.), Sex in advertising: Perspectives on the erotic appeal (pp. 247-269). Mahwah: Erlbaum.

Langton, R. (2009). Sexual solipsism: Philosophical essays on pornography and objectification. Oxford: Oxford University Press.

Lanis, K., \& Covell, K. (1995). Images of women in advertisements: Effects on attitudes related to sexual aggression. Sex Roles, 32, 639-649. https://doi.org/10.1007/BF01544216.

Latané, B., \& Darley, J. M. (1970). The unresponsive bystander: Why doesn't he help? New York: Appleton-Century Crofts.

Lauzen, M. (2017). Women on screen and behind the scenes in television. Center for the Study of Women in Television \& Film, San Diego State University. Retrieved from https://womenintvfilm.sdsu.edu/ wp-content/uploads/2017/09/2016-17_Boxed_In_Report.pdf. Accessed Sept 2018.

Leidig, M. W. (1992). The continuum of violence against women: Psychological and physical consequences. Journal of American College Health, 40, 149-155. https://doi.org/10.1080/07448481. 1992.9936276.

LeMaire, K. L., Oswald, D. L., \& Russell, B. L. (2016). Labeling sexual victimization experiences: The role of sexism, rape myth acceptance, and tolerance for sexual harassment. Violence and Victims, 31, 332-346. https://doi.org/10.1891/0886-6708.VV-D-14-00149.

Leskinen, E. A., Cortina, L. M., \& Kabat, D. B. (2011). Gender harassment: Broadening our understanding of sex-based harassment at work. Law and Human Behavior, 35, 25-39. https://doi.org/10. 1007/s10979-010-9241-5.

Levant, R. F., Hirsch, L., Celentano, E., Cozza, T., Hill, S., MacEachern, M., ... Schnedeker, J. (1992). The male role: An investigation of norms and stereotypes. Journal of Mental Health Counseling, 14, 325-337.

Liao, L., Chang, L., Lee, C., \& Tsai, S. (2020). The effects of a television drama-based media literacy initiative on Taiwanese adolescents' gender role attitudes. Sex Roles, 82, 219-231. https://doi.org/10. 1007/s11199-019-01049-5.

Linz, D. G., Donnerstein, E., \& Penrod, S. (1988). Effects of long-term exposure to violent and sexually degrading depictions of women. Journal of Personality and Social Psychology, 55, 758-768. https:// doi.org/10.1037/0022-3514.55.5.758.

Liss, M., Erchull, M. J., \& Ramsey, L. R. (2011). Empowering or oppressing? Development and exploration of the enjoyment of Sexualization scale. Personality and Social Psychology Bulletin, 37, 55-68. https://doi.org/10.1177/0146167210386119.

Livingstone, S. M. (1990). Interpreting a television narrative: How different viewers see a story. Journal of Communication, 40(1), 72-85. https://doi.org/10.1111/j.1460-2466.1990.tb02252.x.

Loughnan, S., \& Pacilli, M. G. (2014). Seeing (and treating) others as sexual objects: Toward a more complete mapping of sexual objectification. TPM: Testing, Psychometrics, Methodology in Applied Psychology, 21, 309-325. https://doi.org/10.4473/TPM21.3.6.

Loughnan, S., Haslam, N., Murnane, T., Vaes, J., Reynolds, C., \& Suitner, C. (2010). Objectification leads to depersonalization: The denial of mind and moral concern to objectified others. European Journal of Social Psychology, 40, 709-717. https://doi.org/10.1002/ ejsp.755.

Loughnan, S., Baldissarri, C., Spaccatini, F., \& Elder, L. (2017). Internalizing objectification: Objectified individuals see themselves as less warm, competent, moral, and human. British Journal of 
Social Psychology, 56, 217-232. https://doi.org/10.1111/bjso. 12188.

Lynch, T., Tompkins, J. E., van Driel, I. I., \& Fritz, N. (2016). Sexy, strong, and secondary: A content analysis of female characters in video games across 31 years. Journal of Communication, 66, 564 584. https://doi.org/10.1111/jcom.12237.

Maass, A., Cadinu, M., Guarnieri, G., \& Grasselli, A. (2003). Sexual harassment under social identity threat: The computer harassment paradigm. Journal of Personality and Social Psychology, 85, 853870. https://doi.org/10.1037/0022-3514.85.5.853.

Maass, A., Cadinu, M., \& Galdi, S. (2013). Motivations and consequences of sexual harassment. In M. K. Ryan \& N. R. Branscombe (Eds.), The SAGE handbook of gender and psychology (pp. 341-358). London: Sage.

Macrae, C. N., Stangor, C., \& Hewstone, M. (1996). Stereotypes and stereotyping. New York: Guilford Press.

Magley, V. J., Waldo, C. R., Drasgow, F., \& Fitzgerald, L. F. (1999). The impact of sexual harassment on military personnel: Is it the same for men and women? Military Psychology, 11, 283-302. https://doi.org/ 10.1207/s15327876mp1103 5.

Mahalik, J. R., Morray, E. B., Coonerty-Femiano, A., Ludlow, L. H., Slattery, S. M., \& Smiler, A. (2005). Development of the conformity to feminine norms inventory. Sex Roles, 52, 417-435. https://doi. org/10.1007/s11199-005-3709-7.

Martins, Y., Tiggemann, M., \& Kirkbride, A. (2007). Those speedos become them: The role of self-objectification in gay and heterosexual men's body image. Personality and Social Psychology Bulletin, 33, 634-647. https://doi.org/10.1177/0146167206297403.

McDade-Montez, E., Wallander, J., \& Cameron, L. (2017). Sexualization in US Latina and white girls' preferred children's television programs. Sex Roles, 77, 1-15. https://doi.org/10.1007/s11199-0160692-0.

McDermott, R. C., Kilmartin, C., McKelvey, D. K., \& Kridel, M. M. (2015). College male sexual assault of women and the psychology of men: Past, present, and future directions for research. Psychology of Men \& Masculinity, 16, 355-366. https://doi.org/10.1037/ a0039544.

McDonald, P., \& Charlesworth, S. (2016). Workplace sexual harassment at the margins. Work, Employment and Society, 30, 118-134. https:// doi.org/10.1177/0950017014564615.

McMahon, S., \& Banyard, V. L. (2012). When can I help? A conceptual framework for the prevention of sexual violence through bystander intervention. Trauma, Violence \& Abuse, 13, 3-14. https://doi.org/ $10.1177 / 1524838011426015$.

McMahon, S., Postmus, J. L., \& Koenick, R. A. (2011). Conceptualizing the engaging bystander approach to sexual violence prevention on college campuses. Journal of College Student Development, 52, 115-130. https://doi.org/10.1353/csd.2011.0002.

Meraviglia, M. G., Becker, H., Rosenbluth, B., Sanchez, E., \& Robertson, T. (2003). The expect respect project: Creating a positive elementary school climate. Journal of Interpersonal Violence, 18, 1347-1360. https://doi.org/10.1177/0886260503257457.

Mikorski, R., \& Szymanski, D. M. (2017). Masculine norms, peer group, pornography, Facebook, and men's sexual objectification of women. Psychology of Men \& Masculinity, 18, 257-267. https://doi.org/ $10.1037 /$ men0000058.

Millburn, M. A., Mather, R., \& Conrad, S. D. (2000). The effects of viewing R-rated movie scenes that objectify women on perceptions of date rape. Sex Roles, 43, 645-664. https://doi.org/10.1023/A: 1007152507914.

Montemurro, B. (2003). Not a laughing matter: Sexual harassment as "material" on workplace-based situation comedies. Sex Roles, 48, 433-445. https://doi.org/10.1023/A:1023578528629.

Morris, K. L., Goldenberg, J., \& Boyd, P. (2018). Women as animals, women as objects: Evidence for two forms of objectification.
Personality and Social Psychology Bulletin, 44, 1032-1314. https://doi.org/10.1177/0146167218765739.

Murnen, S. K., Wright, C., \& Kaluzny, G. (2002). If "boys will be boys", then girls will be victims? A meta-analytic review of the research that relates masculine ideology to sexual aggression. Sex Roles, 46, 359-375. https://doi.org/10.1023/A:1020488928736.

Nelson, M. R., \& Paek, H. J. (2005). Cross-cultural differences in sexual advertising content in a transnational women's magazine. Sex Roles, 53, 371-383. https://doi.org/10.1007/s11199-005-6760-5.

Nickerson, A. B., Aloe, A. M., Livingston, J. A., \& Feeley, T. H. (2014). Measurement of the bystander intervention model for bullying and sexual harassment. Journal of Adolescence, 37, 391-400. https:// doi.org/10.1016/j.adolescence.2014.03.003.

Nussbaum, M. C. (1995). Objectification. Philosophy \& Public Affairs, 24, 249-291. https://doi.org/10.1111/j.1088-4963.1995.tb00032.x.

O'Leary-Kelly, A. M., \& Bowes-Sperry, L. (2001). Sexual harassment as unethical behavior: The role of moral intensity. Human Resource Management Review, 11, 73-92. https://doi.org/10.1016/S10534822(00)00041-3.

O’Leary-Kelly, A. M., Bowes-Sperry, L., Bates, C. A., \& Lean, E. R. (2009). Sexual harassment at work: A decade (plus) of progress. Journal of Management, 35, 503-536. https://doi.org/10.1177/ 0149206308330555.

Osborne, R. L. (1995). The continuum of violence against women in Canadian universities: Toward a new understanding of the chilly campus climate. Women's Studies International Forum, 18, 637646. https://doi.org/10.1016/0277-5395(95)80100-4.

Pacilli, M. G., Pagliaro, S., Loughnan, S., Gramazio, S., Spaccatini, F., \& Baldry, A. C. (2017). Sexualization reduces helping intentions towards female victims of intimate partner violence through mediation of moral patiency. British Journal of Social Psychology, 56, 293313. https://doi.org/10.1111/bjso.12169.

Pacilli, M. G., Spaccatini, F., Barresi, C., \& Tomasetto, C. (2019). Less human and help-worthy: Sexualization affects children's perceptions of and intentions toward bullied peers. International Journal of Behavioral Development, 43, 481-491. https://doi.org/10.1177/ 0165025419873040

Page, T. E., \& Pina, A. (2015). Moral disengagement as a self-regulatory process in sexual harassment perpetration at work: A preliminary conceptualization. Aggression and Violent Behavior, 21, 73-84. https://doi.org/10.1016/j.avb.2015.01.004.

Piccoli, V., Carnaghi, A., Bianchi, F., \& Del Missier, F. (2016). Donne e uomini nella ricerca Google: Il ruolo del sessismo ambivalente e dell'oggettivazione delle donne [women and men in Google: The role of ambivalent sexism and objectification of women]. Paper presented at the XIV ${ }^{\circ}$ AIP National Congress. Napoli, Italy.

Pina, A., Gannon, T. A., \& Saunders, B. (2009). An overview of the literature on sexual harassment: Perpetrator, theory, and treatment issues. Aggression and Violent Behavior, 14, 126-138. https://doi. org/10.1016/j.avb.2009.01.002.

Preddie, J. P., \& Biernat, M. (2020). More than the sum of its parts: Intersections of sexual orientation and race as they influence perceptions of group similarity and stereotype content. Sex Roles. Advance online publication. https://doi.org/10.1007/s11199-020-01185-3

Prieler, M., \& Centeno, D. (2013). Gender representation in Philippine television advertisements. Sex Roles, 69, 276-288. https://doi.org/ 10.1007/s11199-013-0301-4.

Pryor, J. (1987). Sexual harassment proclivities in men. Sex Roles, 17, 269-290. https://doi.org/10.1007/BF0028845.

Pryor, J. B., LaVite, C. M., \& Stoller, L. M. (1993). A social psychological analysis of sexual harassment: The person/situation interaction. Journal of Vocational Behavior, 42, 68-83. https://doi.org/10.1006/ jvbe.1993.1005.

Puvia, E., \& Vaes, J. (2013). Being a body: Women's appearance related self-views and their dehumanization of sexually objectified female 
targets. Sex Roles, 68, 484-495. https://doi.org/10.1007/s11199012-0255-y.

Quinn, B. A. (2002). Sexual harassment and masculinity: The power and meaning of "girl watching". Gender and Society, 16, 386-402. https://doi.org/10.1177/0891243202016003007.

Reichl, A. J., Ali, J. I., \& Uyeda, K. (2018). Latent sexism in print ads increases acceptance of sexual assault. SAGE Open, 8, 1-11. https:// doi.org/10.1177/2158244018769755.

Rodgers, R. F., McLean, S. A., \& Paxton, S. J. (2019). When seeing is not believing: An examination of the mechanisms accounting for the protective effect of media literacy on body image. Sex Roles, 81, 87-96. https://doi.org/10.1007/s11199-018-0973-x.

Rousseau, A., Rodgers, R. F., \& Eggermont, S. (2019). Short-term longitudinal exploration of the impact of TV exposure on objectifying attitudes toward women in early adolescent boys. Sex Roles, 80, 186-199. https://doi.org/10.1007/s11199-018-0925-5.

Rudman, L. A., \& Borgida, E. (1995). The afterglow of construct accessibility: The behavioral consequences of priming men to view women as sexual objects. Journal of Experimental Social Psychology, 31, 493-517. https://doi.org/10.1006/jesp.1995.1022.

Rudman, L. A., \& Mescher, K. (2012). Of animals and objects: Men's implicit dehumanization of women and likelihood of sexual aggression. Personality and Social Psychology Bulletin, 38, 734-746. https://doi.org/10.1177/0146167212436401.

Sanna, L. J., \& Schwarz, N. (2004). Integrating temporal biases: The interplay of focal thoughts and accessibility experiences. Psychological Science, 15, 474-481. https://doi.org/10.1111/j. 0956-7976.2004.00704.x.

Schank, R. C., \& Abelson, R. P. (1977). Scripts, plans, goals, and understanding. Hillsdale: Erlbaum.

Scharrer, E., \& Blackburn, G. (2018). Cultivating conceptions of masculinity: Television and perceptions of masculine gender role norms. Mass Communication and Society, 21, 149-177. https://doi.org/10. 1080/15205436.2017.1406118.

Schmidt, A. F., \& Kistemaker, L. M. (2015). The sexualized-bodyinversion hypothesis revisited: Valid indicator of sexual objectification or methodological artifact? Cognition, 134, 77-84. https://doi. org/10.1016/j.cognition.2014.09.003.

Schneider, K. T., Swan, S., \& Fitzgerald, L. F. (1997). Job-related and psychological effects of sexual harassment in the workplace: Empirical evidence from two organizations. Journal of Applied Psychology, 82, 401-415. https://doi.org/10.1037/0021-9010.82.3. 401.

Schooler, D., Ward, L. M., Merriwether, A., \& Caruthers, A. (2004). Who's that girl: Television's role in the body image development of young white and black women. Psychology of Women Quarterly, 28, 38-47. https://doi.org/10.1111/j.1471-6402.2004.00121.x.

Seabrook, R. C., Ward, L. M., \& Giaccardi, S. (2018). Why is fraternity membership associated with sexual assault? Exploring the roles of conformity to masculine norms, pressure to uphold masculinity, and objectification of women. Psychology of Men \& Masculinity, 19, 3 13. https://doi.org/10.1037/men0000076.

Singer, T., Seymour, B., O'doherty, J., Kaube, H., Dolan, R. J., \& Frith, C. D. (2004). Empathy for pain involves the affective but not sensory components of pain. Science, 303, 1157-1162. https://doi.org/ 10.1126/science. 1093535

Smith, S. L., Choueiti, M., Pieper, K., Yao, K., Case, A., \& Choi, A. (2019). Inequality in 1,200 popular films: Examining portrayals of gender, racelethnicity, LGBTQ \& disability from 2007 to 2018. USC Annenberg inclusion initiative. Retrieved from http://assets. uscannenberg.org/docs/aii-inequality-report-2019-09-03.pdf. Accessed Mar 2020

Spaccatini, F., Pacilli, M. G., Giovannelli, I., Roccato, M., \& Penone, G. (2019). Sexualized victims of stranger harassment and victim blaming: The moderating role of right-wing authoritarianism. Sexuality and Culture, 23, 1-15. https://doi.org/10.1007/s12119-019-095929.

Sprecher, S., \& McKinney, K. (1993). Sexuality. Newbury Park: Sage.

Srull, T. K., \& Wyer, R. S. (1979). The role of category accessibility in the interpretation of information about persons: Some determinants and implications. Journal of Personality and Social Psychology, 37, 1660-1672. https://doi.org/10.1037/0022-3514.37.10.1660.

Srull, T. K., \& Wyer, R. S. (1989). Person memory and judgment. Psychological Review, 96, 58-83. https://doi.org/10.1037/0033295X.96.1.58

Stankiewicz, J. M., \& Roselli, F. (2008). Women as sex objects and victims in print advertisements. Sex Roles, 58, 579-589. https:// doi.org/10.1007/s11199-007-9359-1.

Stockdale, M. S., \& Nadler, J. T. (2012). Situating sexual harassment in the broader context of interpersonal violence: Research, theory, and policy implications. Social Issues and Policy Review, 6, 148-176. https://doi.org/10.1111/j.1751-2409.2011.01038.x.

Stop Street Harassment. (2018). The facts behind the \#MeToo movements: A national study on sexual harassment and assault. Reston, VA. Retrieved from http://www.stopstreetharassment.org/ wp-content/uploads/2018/01/Full-Report-2018-National-Study-onSexual-Harassment-and-Assault.pdf. Accessed May 2019.

Stout, K. D. (1991). A continuum of male controls and violence against women: A teaching model. Journal of Social Work, 27, 305-320. https://doi.org/10.1080/10437797.1991.10672203.

Street, A. E., Stafford, J., Mahan, C. M., \& Hendricks, A. (2008). Sexual harassment and assault experienced by reservists during military service: Prevalence and health correlates. Journal of Rehabilitation Research and Development, 45, 409-420. https://doi.org/10.1682/ JRRD.2007.06.0088.

Strouse, J. S., Goodwin, M. P., \& Roscoe, B. (1994). Correlates of attitudes toward sexual harassment among early adolescents. Sex Roles, 31, 559-577. https://doi.org/10.1007/BF01544280.

Tajfel, H., \& Turner, J. C. (1986). The social identity theory of intergroup behaviour. In S. Worchel \& W. G. Austin (Eds.), The psychology of intergroup relations (pp. 7-24). Chicago: Nelson-Hall.

Tarr, M. J. (2013). Perception isn't so simple: Commentary on Bernard, Gervais, Allen, Campomizzi, and Klein (2012). Psychological Science, 24, 1069-1070. https://doi.org/10.1177/ 0956797612474669.

Tylka, T. L., \& Augustus-Horvath, C. L. (2011). Fighting selfobjectification in prevention and intervention contexts. In R. Calogero, S. Tantleff-Dunn, \& J. Thompson (Eds.), Self-objectification in women: Causes, consequences, and counteractions (pp. 187-214). Washington, DC: American Psychological Association.

U.S. Equal Employment Opportunity Commission. (2012). Facts about sexual harassment. Retrieved from https://www.eeoc.gov/eeoc/ publications/fs-sex.cfm. Accessed Sept 2012.

Vaes, J., Paladino, P., \& Puvia, E. (2011). Are sexualized women complete human beings? Why men and women dehumanize sexually objectified women. European Journal of Social Psychology, 41, 774-785. https://doi.org/10.1002/ejsp.824.

Vaes, J., Loughnan, S., \& Puvia, E. (2014). The inhuman body: When sexual objectification becomes dehumanizing. In P. G. Bain, J. Vaes, \& J.-P. Leyens (Eds.), Humanness and dehumanization (pp. 187-204). New York: Taylor \& Francis.

Vaes, J., Cristoforetti, G., Ruzzante, D., Cogoni, C., \& Mazza, V. (2019). Assessing neural responses towards objectified human targets and objects to identify processes of sexual objectification that go beyond the metaphor. Scientific Reports, 9, 6699. https://doi.org/10.1038/ s41598-019-42928-x.

Valtorta, R. R., Sacino, A., Baldissarri, C., \& Volpato, C. (2016). L'eterno femminino. Stereotipi di genere e sessualizzazione nella pubblicità televisiva. Psicologia Sociale, 11, 159-188. https://doi. org/10.1482/84097. 
Vance, K., Sutter, M., Perrin, P. B., \& Heesacker, M. (2015). The media's sexual objectification of women, rape myth acceptance, and interpersonal violence. Journal of Aggression, Maltreatment \& Trauma, 24, 569-587. https://doi.org/10.1080/10926771.2015.1029179.

Vandenbosch, L., Vervloessem, D., \& Eggermont, S. (2013). "I might get your heart racing in my skin-tight jeans": Sexualization on music entertainment television. Communication Studies, 64, 178-194. https://doi.org/10.1080/10510974.2012.755640.

Ward, L. M. (2002). Does television exposure affect emerging adults' attitudes and assumptions about sexual relationships? Correlational and experimental confirmation. Journal of Youth and Adolescence, 31, 1-15. https://doi.org/10.1023/A:1014068031532.

Ward, L. M. (2016). Media and sexualization: State of empirical research, 1995-2015. The Journal of Sex Research, 53, 560-577. https://doi. org/10.1080/00224499.2016.1142496.

Ward, L. M., \& Friedman, K. (2006). Using TV as a guide: Associations between television viewing and adolescents' sexual attitudes and behavior. Journal of Research on Adolescence, 16, 133-156. https://doi.org/10.1111/j.1532-7795.2006.00125.x.

Ward, L. M., Hansbrough, E., \& Walker, E. (2005). Contributions of music video exposure to black adolescents' gender and sexual schemas. Journal of Adolescent Research, 20, 143-166. https:// doi.org/10.1177/0743558404271135.

Ward, L. M., Rivadeneyra, R., Thomas, K., Day, K., \& Epstein, M. (2013). A woman's worth: Analyzing the sexual objectification of black women in music videos. In E. L. Zurbriggen \& T. A. Roberts (Eds.), The sexualization of girls and girlhood: Causes, consequences, and resistance (pp. 39-62). New York: Oxford University Press.

Wegner, D. M. (1994). Ironic processes of mental control. Psychological Review, 101, 34-52. https://doi.org/10.1037/0033-295X.101.1.34.

Willness, C. R., Steel, P., \& Lee, K. (2007). A meta-analysis of the antecedents and consequences of workplace sexual harassment. Personnel Psychology, 60, 127-162. https://doi.org/10.1111/j. 1744-6570.2007.00067.x.

Wright, P. J. (2011). Mass media effects on youth sexual behavior assessing the claim for causality. Annals of the International Communication Association, 35, 343-385. https://doi.org/10.1080/ 23808985.2011.11679121.

Wright, P. J., \& Funk, M. (2014). Pornography consumption and opposition to affirmative action for women: A prospective study.
Psychology of Women Quarterly, 38, 208-221. https://doi.org/10. 1177/0361684313498853.

Wright, P. J., \& Tokunaga, R. S. (2015). Activating the centerfold syndrome: Recency of exposure, sexual explicitness, past exposure to objectifying media. Communication Research, 42, 864-897. https:// doi.org/10.1177/0093650213509668.

Wright, P. J., \& Tokunaga, R. S. (2016). Men's objectifying media consumption, objectification of women, and attitudes supportive of violence against women. Archives of Sexual Behavior, 45, 955-964. https://doi.org/10.1007/s10508-015-0644-8.

Wright, P. J., Malamuth, N. M., \& Donnerstein, E. (2012). Research on sex in the media: What do we know about effects on children and adolescents? In D. G. Singer \& J. L. Singer (Eds.), Handbook of children and the media (pp. 273-302). Thousand Oaks: Sage.

Wright, P. J., Tokunaga, R. S., \& Kraus, A. (2016). A meta-analysis of pornography consumption and actual acts of sexual aggression in general population studies. Journal of Communication, 66, 183205. https://doi.org/10.1111/jcom.12201.

Yang, W., Jin, S., He, S., Fan, Q., \& Zhu, Y. (2015). The impact of power on humanity: Self-dehumanization in powerlessness. PLoS One, 10, e0125721. https://doi.org/10.1371/journal.pone.0125721.

Yao, M. Z., Mahood, C., \& Linz, D. (2010). Sexual priming, gender stereotyping, and likelihood to sexually harass: Examining the cognitive effects of playing a sexually-explicit video game. Sex Roles, 62, 77-88. https://doi.org/10.1007/s11199-009-9695-4.

Zanardo, L., Chindemi, M. M., \& Cantù, C. (2009). Il corpo delle donne [Women's body]. Retrieved from http://www.ilcorpodelledonne.net/ english-version/. Accessed Sept 2012.

Zarate, M. A., \& Smith, E. R. (1990). Person categorization and stereotyping. Social Cognition, 8, 161-185. https://doi.org/10. 1521/soco.1990.8.2.161.

Zawisza, M., Luyt, R., Zawadzka, A. M., \& Buczny, J. (2018). Crosscultural sexism and the effectiveness of gender (non)traditional advertising: A comparison of purchase intentions in Poland, South Africa, and the United Kingdom. Sex Roles, 79, 738-751. https:// doi.org/10.1007/s11199-018-0906-8.

Publisher's Note Springer Nature remains neutral with regard to jurisdictional claims in published maps and institutional affiliations. 